\title{
Democratizing the Delivery of Legal Services
}

\author{
RENEE NEWMAN KNAKE*
}

One of the most significant problems faced by the legal profession in the twenty-first century is the ineffective delivery of legal services. Millions in need of legal representation are unable to afford a lawyer and thousands of lawyers are unemployed. We are desperate for a solution to democratize access to the law through efficient and affordable delivery of legal services.

Noted law scholars and economists have argued over the years that corporate ownership of law firms can offer a solution to this problem. For example, corporations like Wal-Mart or Google are especially adept at disseminating services and information to the mass public. These kinds of corporations are also financially situated to make substantial capital outlays and await a later return on the investment. Both of these attributes make corporate ownership of law firms an appealing avenue for increasing access to legal services. Yet professional conduct rules in all fifty states and the District of Columbia ban corporations from owning or investing in law firms.

This Article identifies a First Amendment jurisprudential thread that establishes important constitutional interests in the delivery of legal services by corporations through the ownership of law practices. The Supreme Court initially recognized First Amendment protection for the delivery of legal services by a corporate entity in NAACP $\mathrm{v}$. Button and most recently confirmed in Citizens United v. FEC that a corporation, whether nonprofit or for-profit, enjoys the same free speech rights as an individual. Under this precedent, blanket bans on corporate investment in law practices are unlikely to survive. This expanded understanding of First Amendment rights for corporations parallels the economic realities of modern law practice and the regulatory changes underway in the United Kingdom and Australia. Now is the time to embrace the benefits that can accrue from corporate ownership, in

* Associate Professor of Law \& Co-Director, Kelley Institute of Ethics and the Legal Profession, Michigan State University College of Law. This Article was competitively selected by the Section on Professional Responsibility for presentation at the 2012 Annual Meeting of the Association of American Law Schools, and I am grateful for the honor and opportunity to receive helpful feedback at that event, especially from Adam Liptak, David McGowan, and David Udell. An early draft of this Article was presented at the University of the Pacific McGeorge School of Law Symposium on Ethics 20/20-Globalization, Technology, and Transforming the Practice of Law, April 2011, and I thank Paul Paton as well as the participants for their comments. The Article also benefited from presentations at the Arizona State University, Michigan State University, and the University of Tennessee. I am indebted to Ronald K.L. Collins for suggesting that I explore this topic, and I extend him a special thanks for incredibly helpful comments on a very early draft. Mae Kuykendall also deserves thanks for providing thoughtful feedback on an early draft, as do Laurel Terry and David Blankfein-Tabachnick for insightful suggestions as the Article neared completion. And to Mae, I also express my gratitude for fulfilling Virginia Woolf's instruction that "a woman must have money and a room of her own if she is to write," and for making sure I had a room of my own here at Michigan State. Finally, I thank Michigan State University College of Law for support, including the award of a generous summer research stipend. 
particular the democratization of law through the delivery of more accessible and affordable legal services.

\section{TABLE OF CONTENTS}

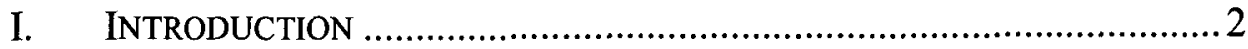

II. IN A CITIZENS UNITED WORLD, WHAT REMAINS OF STATE

Professional CONDUCT RULES BANNING CORPORATE

OWNERSHIP OF LAW FIRMS?.......................................................... 11

III. FROM NAACP V. BUTTON TO CITIZENS UNITED V. FEC:

ESTABLISHING THE CORPORATION'S FIRST AMENDMENT RIGHT TO

Deliver Legal Services Through Law Practice

OWNERSHIP/INVESTMENT

A. The First Amendment Value in the Delivery of Legal Services and NAACP v. Button

B. Legal Advocacy/Advice as Protected Speech and Legal Services Corp. v. Velazquez .....................................................23

C. The Commercial Speech Cases and Bates v. State Bar ............25

D. Ohralik v. Ohio State Bar Association and In re Primus...........31

E. Corporate Speech: Citizens United v. FEC..............................33

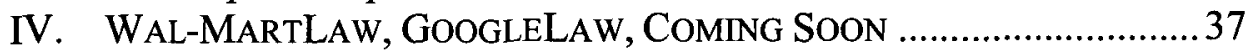

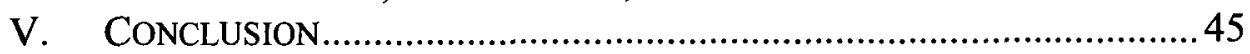

\section{INTRODUCTION}

One of the most significant problems faced by the legal profession in the twenty-first century is the ineffective delivery of legal services. Millions in need of representation cannot afford to hire a lawyer, ${ }^{1}$ let alone make an informed decision about the best-suited lawyer for their needs. Indeed, many do not even realize when a lawyer might be necessary or helpful. A nation that holds itself out as a beacon of justice and an exemplar of the rule of law to the rest of the world denies meaningful access to the law on a daily basis to the majority of its population. Lawyers are out of reach for most individuals unless they enjoy extreme affluence or subsist at poverty levels. ${ }^{2}$

${ }^{1}$ In New York State, for example, "some 2.3 million people a year ... cannot afford representation" for "civil cases that deal with 'the essentials of life' like eviction and child support." William Glaberson, Judge's Budget Will Seek Big Expansion of Legal Aid to the Poor in Civil Cases, N.Y. TiMES, Nov. 29, 2010, at A21; see also infra note 180.

2 See Glaberson, supra note 1; see also RICHARD SUSSKIND, THE END OF LAWYERS?: RETHINKING THE NATURE OF LEGAL SERVICES 235 (2008) (observing that "solving legal problems and resolving disputes is affordable, in practice, only to the very rich or those who are eligible for some kind of state support"). 
This unmet need is not due to a lack of lawyers. Law schools are graduating new attorneys at an unprecedented rate, ${ }^{3}$ and thousands of unemployed attorneys ${ }^{4}$ are eager to offer their services. One might think that an easy solution to this problem would be for these lawyers to simply set up solo or small practices in the local community, and the clients could then find them. Or, one might propose that government and nonprofit legal aid organizations expand legal assistance, or that lawyers ratchet up their pro bono hours. To date, these solutions have not proven effective. 5 These solutions are not likely to offer the revolutionary sort of change that is needed for the delivery of legal services today.

Our commercialized, technology-driven, and increasingly global society demands an entirely new framework for the delivery of legal services. This observation necessarily begs several questions. How do we effectively match clients to lawyers in a way that is affordable to the client but allows the lawyer to make a living without the burdens and conflicts wrought by an extraordinary caseload or the pressure of billable hours? How do we educate and inform the public about the law so they understand when the services of a lawyer are necessary or desirable? How do we preserve lawyer independence and a vibrant rule of law culture while simultaneously cultivating new opportunities for legal assistance? In other words, how do we increase the speech about access to the law?

Access to the law-that is, facilitating and delivering legal services-goes to the very heart of First Amendment concerns and values by contributing to Justice Holmes's marketplace of ideas, ${ }^{6}$ acting as a checkpoint on government

${ }^{3}$ Approximately 43,000 law degrees were distributed in 2009 , an $11 \%$ increase from a decade ago in 1999. The Great Law School 'Rip-off': By the Numbers, THE WEEK (Jan. 11, 2011, 2:50 PM), http://theweek.com/article/index/210930/the-great-law-school-rip-off-bythe-numbers.

${ }^{4}$ See, e.g., Layoff Tracker, LAW SHUCKS: LIFE IN \& AFTER BIGLAW, http://lawshucks.com/layoff-tracker/ (last visited Feb. 1, 2012) ("As of December 11, 2011, over 15,435 people have been laid off by major law firms $(5,872$ lawyers $/ 9,563$ staff $)$ since January 1, 2008."). Significantly, this data does not include layoffs that occurred in small or mid-sized firms, solo practices, or government offices, nor does it include layoffs pre-2008 or post-December 2011.

${ }^{5}$ If anything, the situation is at risk of worsening. As one indicator, at the time of this writing, Congress is considering the Spending Reduction Act of 2011, which, among other things, would eliminate all funding for the Legal Services Corporation, the primary provider of legal aid in the United States for non-criminal matters ( $\$ 420$ million annually). See Jim Jordan, Spending Reduction Act of 2011, REPUBLICAN STUDY COMMITTEE, 1 (Jan. 2011), http://rsc.jordan.house.gov/UploadedFiles/Spending_Reduction_Act--TWOPAGER.pdf; see also SUSSKIND, supra note 2, at 235 ("One possibility is to increase state funding of legal services. ... [T] his looks very unlikely to happen, not least because justice (especially civil justice) tends to compete poorly with other demands on the public purse ....").

${ }^{6}$ See Abrams v. United States, 250 U.S. 616, 630 (1919) (Holmes, J., dissenting) ("[T] $[$ he ultimate good desired is better reached by free trade in ideas-that the best test of truth is the power of the thought to get itself accepted in the competition of the market...."). For a thoughtful explanation of Justice Holmes's use of the marketplace 
action, ${ }^{7}$ facilitating individual development, ${ }^{8}$ and cultivating political discourse. ${ }^{9}$ One of the biggest obstacles compromising access to legal services in the United States is delivery. Individuals lack information about their legal needs. They do not know where to find a lawyer, other than in the yellow pages, or perhaps by searching the Internet, where advertising by personal injury lawyers and settlement mills dominates. ${ }^{10}$ Lawyers similarly struggle to deliver affordable, effective service, especially outside of the high-end private law firm context.

In some ways, speech about access to the law is protected from government restriction. Advertising is an example of speech about access to the law. In Bates v. State Barll the Supreme Court held that blanket bans against advertising by lawyers violate the First Amendment. ${ }^{12}$ The Court recognized not only important free speech interests for lawyers in communicating about their services, but also for individuals in obtaining access to the law. ${ }^{13}$ Significantly, in overturning the advertising ban, the Court observed that it "likely has served to burden access to legal services, particularly for the notquite-poor and the unknowledgeable." 14 While Bates involved commercial speech, the Court seemed to apply a stronger form of Central Hudson ${ }^{15}$ scrutiny to protect attorney advertising because it was speech about access to the law. Additional constitutional protections that support access to the law include the Sixth Amendment's right to effective assistance of counsel ${ }^{16}$ and voting rights. ${ }^{17}$

concept, see Ronald K.L. Collins, Holmes' Idea Marketplace-Its Origins and Legacy, FIRST AMENDMENT CENTER (May 13, 2010), http://www.firstamendmentcenter.org/ commentary.aspx?id=22945. See also JOHN STUART MILL, ON LIBERTY 41 (David Bromwich \& George Kateb eds., Yale Univ. Press 2003) (1859) ("Wrong opinions and practices gradually yield to fact and argument: but facts and arguments, to produce any effect on the mind, must be brought before it.").

${ }^{7}$ See Vincent Blasi, The Checking Value in First Amendment Theory, 1977 AM. B. FOUND. RES. J. 521, 527. Vincent Blasi's "checking value" demands protection of speech that can "serve in checking the abuse of power by public officials." Id.

${ }^{8}$ See generally Thomas Scanlon, $\boldsymbol{A}$ Theory of Freedom of Expression, 1 PHIL. \& PUB. AFF. 204, 215-22 (1972) (discussing the role of autonomy in the context of free expression).

${ }^{9}$ See, e.g., AleXander Meiklejohn, Free Speech and Its Relation to Self GOVERNMENT 96-98 (1948) (credited with establishing the modern understanding of First Amendment political speech); CASS SUNSTEIN, DEMOCRACY AND THE PROBLEM OF FREE SPEECH 130 (1993) (treating speech as political "when it is both intended and received as a contribution to public deliberation about some issue" (emphasis omitted)).

${ }^{10}$ For a discussion of advertising by so-called "settlement mills," see Nora Freeman Engstrom, Run-of-the-Mill Justice, 22 GEO. J. LEGAL ETHICS 1485, 1492-93 (2009).

11433 U.S. 350 (1977).

12 Id. at 384 .

${ }^{13}$ Id.

${ }^{14}$ Id. at 376-77.

15 See infra discussion of Central Hudson at notes 155-56 and accompanying text.

${ }^{16}$ See U.S. CONST. amend. VI ("In all criminal prosecutions, the accused shall enjoy. . . the Assistance of Counsel for his defense."). But see Jones v. Barnes, 463 U.S. 
But in other ways-important ways - speech about access to the law remains unprotected, a troubling reality given the fundamental value of such speech to our democratic government and the rule of law. For example, during the 2009 Term, the Supreme Court declined to decide whether a restriction in a federal bankruptcy statute limiting an attorney's advice to a client could withstand a First Amendment challenge. ${ }^{18}$ That same term, the Court upheld a federal statute prohibiting an attorney from advising a client about how to petition representative bodies like the United Nations or how to negotiate a peace treaty. ${ }^{19}$ As I have written elsewhere, these decisions are problematic because access to legal advice rests at the core of democratic government. ${ }^{20}$ The Court similarly has refused to examine the constitutionality of rules that constrict an attorney's criticism of a judge. ${ }^{21}$ Bans on a lawyer's advice to a client or a lawyer's criticism of the judiciary risk silencing the most knowledgeable source-and in some instances perhaps the only source-of speech about access to the law.

Lawyer discipline and professional conduct rules that forbid corporations from owning or investing in a law firm or law practice ${ }^{22}$ are another form of speech restriction that compromises access to the law. Under rules effective throughout the United States, corporations are prohibited from law practice ownership or investment. ${ }^{23}$ The historic abhorrence for corporate ownership and

745, 764 (1983) (Brennan, J., dissenting) ("In many ways, having a lawyer becomes one of the many indignities visited upon someone who has the ill fortune to run afoul of the criminal justice system.").

${ }^{17}$ See U.S. CONST. amend. XV (forbidding discrimination in voting based on race); id. amend. XIX (forbidding discrimination based on sex); id. amend. XXIV (prohibiting poll taxes); id. amend. XXVI (granting right to vote to citizens over eighteen years of age).

${ }^{18}$ See Milavetz, Gallop \& Milavetz, P.A. v. United States, 130 S. Ct. 1324, 1339 (2010) (declining to "consider whether the [bankruptcy] statute [banning legal advice] so construed withstands First Amendment scrutiny").

${ }^{19}$ See Holder v. Humanitarian Law Project, 130 S. Ct. 2705, 2724 (2010) (applying a "more demanding standard" of review and holding that the antiterrorism material support statute constitutionally prohibits "expert advice or assistance" in the form of advice about petitioning representative bodies like the United Nations or negotiating peace treaties given to a group designated as a foreign terrorist organization).

${ }^{20}$ See Renee Newman Knake, Attorney Advice and the First Amendment, 68 WASH. \& LEE L. REV. 639, 643-44 (2011).

${ }^{21}$ For example, the Supreme Court has denied certiorari twice to cases challenging Michigan's so-called civility rules-Michigan Rules of Professional Conduct 3.5 and 6.5that restrict lawyers' criticism of the judiciary. See Fieger v. Supreme Court, 130 S. Ct. 1048 (2010) (mem.) (cert. denied); Fieger v. Mich. Grievance Adm'r, 549 U.S. 1205 (2007) (mem.) (cert. denied).

${ }^{22}$ I use the term "law practice" primarily in the Article, but it could be interchanged with "law firm," "legal representation," or "legal services," meaning that whether a corporation chooses to purchase an existing law firm, establish its own law practice/legal services delivery system, or sell services from its existing in-house legal department, similar economic and constitutional concerns are at stake.

${ }^{23}$ See MOdel Rules of Prof'L CONDUCT R. 5.4 (2011). 
investment in law practices is purportedly justified by concerns about the preservation of lawyer independence/professionalism and, more specifically, the avoidance of confidentiality breaches and conflicts of interest. ${ }^{24}$ Bar regulators disregard the potential benefit that might be realized by corporate delivery of legal services, reasoning that lawyers' independence and professional reputation as well as clients' security must take precedence. ${ }^{25}$ Such a position, however, ignores the extensive body of professional conduct rules that currently supports these goals and would continue to protect lawyer independence even if corporations engaged in the delivery of legal representation. ${ }^{26}$

Corporations like Google ${ }^{27}$ and Wal-Mart ${ }^{28}$ know a great deal about the delivery of services, goods, and information to the mass public. These corporations and many others have the capacity to make significant financial outlays into innovative mechanisms for providing legal services and await a delayed return on that investment. For example, in January 2011, Google's venture capital arm announced a several-hundred-thousand-dollar investment

${ }^{24}$ See, e.g., Richard C. Weber, Law Firms Should Spurn Outside Investments, Bus. WEEK (Sept. 20, 2011), http://www.businessweek.com/management/law-firms-shouldspurn-outside-investments-09202011.html ("From the very beginning, the lawyer-client relationship has been treated as fundamentally different from a business relationshipbecause it is. The relationship is protected by a unique privilege for attorney-client communication and the professional ethic that lawyers must unequivocally put client interests first.").

${ }^{25}$ See discussion infra notes 51-62 and accompanying text.

${ }^{26}$ The entire body of Model Rules of Professional Conduct arguably furthers the goal of protecting the profession's reputation, but Part 8 of the Model Rules, Maintaining the Integrity of the Profession, is especially targeted to do so. As for protecting clients from conflicts or other concerns that might be associated with nonlawyer ownership or investment, see MODEL RULES OF PROF'L CONDUCT R. 1.7, 1.8, 1.9, \& 1.10 on conflicts of interest, as well as id. R. 1.6 on confidentiality of information.

${ }^{27}$ Given Google's professed mission "to organize the world's information and make it universally accessible and useful," it seems at least plausible, if not a foregone conclusion, that the company might desire to bring its expertise to legal information through ownership of or investment in law firms, or through selling its in-house legal services. See Corporate Information, GoOGLE, http://www.google.com/corporate/index.html (last visited Jan. 30, 2012). Indeed, in November 2009, Google launched a new search engine for legal opinions. See Finding the Laws that Govern Us, OfFiCIAL Google BLOG (Nov. 17, 2009, 9:05 AM), http://googleblog.blogspot.com/2009/11/finding-laws-that-govern-us.html ("Starting today, we're enabling people everywhere to find and read full text legal opinions from U.S. federal and state district, appellate and supreme courts using Google Scholar.").

${ }^{28}$ Lest the example of Wal-Mart seem too far-fetched, it is worth noting that Tesco, the United Kingdom's equivalent to the United States' Wal-Mart, "has been offering legal services in the United Kingdom since at least 2004, when it began to offer advice on divorce, employment and business online." Christopher J. Whelan, The Paradox of Professionalism: Global Law Practice Means Business, 27 PENN ST. INT'L L. REV. 465, 491 n.193 (2008); see also discussion infra notes 218-60 and accompanying text. Wal-Marts across the country already offer services such as optometry and banking. 
into LawPivot, ${ }^{29}$ a website where companies are matched with lawyers to receive crowdsourced ${ }^{30}$ and confidential legal advice. Or consider that Londonbased WHSmith stores began hosting legal kiosks in 500 stores in the fall of 2011 through a partnership with QualitySolicitors, a British legal services provider. ${ }^{31}$ British shoppers can purchase a newspaper and obtain routine legal assistance such as divorce filings, wills, real estate transactions, and basic contracts in the same location. In the United States, Wal-Mart already offers financial and medical services to its customers. ${ }^{32}$ It is not difficult to imagine other alternative law delivery models that might be developed if a company like Google could take the next step to directly own or invest in a law practice, or if Wal-Mart could add a legal assistance window next to the banking center or health care provider located in its stores.

The estimated thirty million households that do not have bank accounts (or use one sparingly) ${ }^{33}$ that Wal-Mart aims to serve by offering financial services are the very same individuals least likely to have access to a lawyer when they would benefit from it. Seventy percent of these households earn less than $\$ 30,000$ annually. ${ }^{34}$ They cannot afford a lawyer who bills by the hour at a three-figure rate, particularly for assistance with issues that they are most apt to need, such as divorce, wills, mortgage foreclosure, child support, or immigration. Professor Richard Susskind, an expert on the United Kingdom's legal profession, predicts that nonlawyer investors like corporations are

${ }^{29}$ See Debra Cassens Weiss, Crowdsourced Legal Answers Website Gets $\$ 600 k$ from Investors, Including Google Ventures, A.B.A. J. ONLINE (Jan. 21, 2011, 11:16 AM),

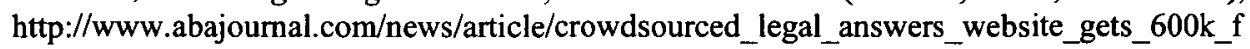
rom_investors_including_googl/ (announcing that LawPivot "is getting $\$ 600,000$ in funding from Google Ventures and individual investors").

${ }^{30}$ Crowdsourced or crowdsourcing is defined as "trying to find a way of completing a task, a solution to a problem, etc. by asking a wide range of people or organisations if they can help, typically by using the Internet." Definition of Crowdsourcing, MACMILLAN DICTIONARY (2011), http://www.macmillandictionary.com/buzzword/entries/crowdsourcing. html.

${ }^{31}$ See Catherine Baksi, Quality Solicitors in WHSmith Tie-up, LAW GAZETTE (Apr. 7, 2011), http://www.lawgazette.co.uk/news/qualitysolicitors-whsmith-tie; John Eligon, Selling Pieces of Law Firms to Investors, N.Y. TIMES, Oct. 29, 2011, at B1 ("England began this month to allow groups other than lawyers to own and control law practices, and some of the country's major retailers have begun offering legal services in their stores and online.").

${ }^{32}$ See, e.g., Ylan Q. Mui, Retailers Take on New Role: Banker, WASH. Post, Feb. 1, 2011, at A12 ("Millions of low-income Americans who don't have bank accounts are finding an alternative to check-cashing stores at an unusual place: their local big-box retailer. ... Wal-Mart has opened roughly 1,500 MoneyCenters that process as many as 5 million transactions each week."); 400 Health Clinics to Open in Wal-Mart Stores in the Next Three Years, Up to 2,000 Could Open Next Five to Seven Years, WAL-MART CORP. (Apr. 24, 2007), http://walmartstores.com/pressroom/news/6419.aspx.

${ }^{33}$ See Mui, supra note 32 ("According to a recent government survey, nearly 30 million households either do not have a bank account or use one sparingly.").

${ }^{34} I d$. ("Nearly 70 percent of families considered 'unbanked' earn less than $\$ 30,000$ a year and many say they will never do business at a bank."). 
attracted to what some might characterize as these "'low-end" legal service[s], such as consumer law and Legal Aid work" because they "see scope for more rigorous processes and the introduction of systems that can radically overhaul the conventional ways of operating." 35 Nonlawyer investors understand that a profit can. be realized by offering these services through "bulk legal processing capabilities" rather than through "myriad sole practioners and small firms across the land." 36 For these and related reasons, noted legal scholars and economists have recommended for decades that corporations be allowed to own and invest in law practices. ${ }^{37}$ Yet the bans endure.

The First Amendment value in the delivery of legal services by corporations has gone largely ignored, notwithstanding the ongoing debate about the practical benefits or consequences of corporate law practice ownership and investment. This Article is the first to identify and discuss in detail a jurisprudential thread establishing the First Amendment interests associated with the delivery of legal services by corporations. The Court initially recognized the First Amendment value of legal services delivery by a corporate entity in NAACP v. Button ${ }^{38}$ and has continued to affirm and expand this proposition over the years. ${ }^{39}$ More recently, in Citizens United $v . F E C,{ }^{40}$ a majority of the Justices confirmed that the First Amendment applies equally to a corporation and individuals, and expanded prior cases on the importance of speech to further economic competition. ${ }^{41}$

In light of this precedent extending over half a century, the blanket suppression of corporate law practice ownership must give way to the First Amendment rights of corporations, lawyers, and individuals associated with the delivery of legal services. This is not to say that a corporation's involvement with a law practice must be left completely unregulated, just that it cannot be prohibited outright. The American Bar Association 20/20 Commission is currently exploring reforms to the Model Rules of Professional Conduct that encompass this very issue. ${ }^{42}$ The First Amendment demands that bar authorities and other regulators embrace-not just explore-the concept of corporate law practice ownership and investment, particularly to the extent such arrangements can democratize law through the delivery of more accessible and affordable legal services. ${ }^{43}$ If they choose not to do so, the matter inevitably will be

${ }^{35}$ SUSSKIND, supra note 2, at 253.

${ }^{36} \mathrm{Id}$.

${ }^{37}$ See discussion infra notes 52-80 and accompanying text.

38371 U.S. 415,429 (1963).

${ }^{39}$ See discussion infra notes 112-19 and accompanying text.

40130 S. Ct. 876 (2010).

${ }^{41}$ See discussion infra notes 194-209 and accompanying text.

42 See Speakers Debate Nonlawyers' Role in Firms at First Ethics 20/20 Commission Hearing, 26 LAW. MANUAL ON Prof. CONDUCT (ABA/BNA) 110 (Feb. 17, 2010), available at http://www.abanet.org/ethics2020/bnart.1.pdf.

${ }^{43}$ To date, the ABA Commission on Ethics 20/20, charged with revision of the Model Rules of Professional Conduct, has declined to recommend nonlawyer ownership and 
decided in the courts - or legislatively, should Congress or the states choose to act. $^{44}$ For example, litigation challenging nonlawyer ownership bans is underway in federal courts in New York, New Jersey, and Connecticut, ${ }^{45}$ and the North Carolina legislature considered a bill to permit corporate ownership of law firms during the 2011 session. ${ }^{46}$

It is important to be precise about the question addressed here: this Article considers neither whether a corporation is entitled to legal advice, nor whether a corporation holds a constitutional right to petition judicial, legislative, and administrative bodies. This Article does not dispute a state's authority to regulate the credentials of those individuals licensed to practice law. ${ }^{47}$ Rather,

investment in this way. See Letter from ABA Comm'n on Ethics 20/20 Working Grp. on Alternative Bus. Structures, For Comment: Issues Paper Concerning Alternative Business Structures, to ABA Entities, Courts, Bar Associations (state, local, specialty and international), Law Schools, and Individuals (Apr. 5, 2011) [hereinafter Letter from ABA Comm'n], available at http://www.americanbar.org/content/dam/aba/administrative/ ethics_2020/abs_issues_paper.authcheckdam.pdf. The Commission has indicated a willingness to consider a proposal that would allow for some forms of minority nonlawyer ownership, but corporations would still be prohibited from being majority owners of law practices. See discussion infra note 243 and accompanying text.

${ }^{44}$ Historically, regulation of the legal profession has been left largely to the states. In recent years, however, Congress has begun to take an increasing interest in regulating the relationship between lawyers and their clients. See, e.g., Holder v. Humanitarian Law Project, 130 S. Ct. 2705, 2724 (2010) (banning certain advice from a lawyer to a client that has been designated as a "foreign terrorist organization"); Milavetz, Gallop \& Milavetz, P.A. v. United States, 130 S. Ct. 1324, 1339 (2010) (banning certain advice from a lawyer to her client about filing for bankruptcy).

${ }^{45}$ In May 2011, the plaintiffs' law firm Jacoby \& Meyers filed three lawsuits challenging the ownership and investment ban in ABA Model Rule 5.4 in New York, New Jersey, and Connecticut. See Mark Hamblett, Suit Challenges N.Y. Prohibition of NonLawyer Firm Ownership, N.Y. L.J. ONLINE (May 20, 2011), http://www.newyorklawjournal.com/PubArticleNY.jsp?id=1202494645339 ("In virtually identical lawsuits filed Wednesday in New York, Connecticut and New Jersey, Jacoby \& Meyers casts its challenge as client-friendly, claiming the ban on nonlawyer investment denies firms the ability to raise outside capital, denying most lawyers 'a critical source of funding' that 'dramatically impedes access to legal services for those otherwise unable to afford them."”).

${ }^{46}$ The bill was introduced by Senator Hartsell in the General Assembly of North Carolina during the 2011 session, and it would have allowed for "nonattomey ownership of professional corporation law firms, subject to certain requirements." S.B. 254, 2011 Gen. Assemb., Reg. Sess. (N.C. 2011), available at http://www.ncleg.net/Sessions/2011/Bills/ Senate/HTML/S254v0.html.

${ }^{47}$ As Professor Andrews notes:

The difference is important. For even if it is agreed that lawyers should be licensed, and that those who cannot meet the licensing requirements should be prohibited from practicing law, it does not follow intuitively or necessarily that nonlawyers should be prohibited from offering their nonlegal resources and talents in a business combination with lawyers practicing law. 
this Article is concerned solely with the question of whether or not a corporation holds a First Amendment right to engage with lawyers for the purpose of delivering legal services (and, of course, whether or not an individual holds a corresponding interest in the delivery of those legal services).

This Article is in some ways descriptive, in that one of my purposes is to document how First Amendment jurisprudence has evolved to support the protection of legal services delivery by corporations. Yet, this also is a novel conclusion and the normative ramifications that flow from it cannot be ignored, particularly given the economic realities of modern law practice and the emerging deregulation of the legal profession occurring in other countries. Corporate ownership of law practices has the potential to democratize the delivery of legal services in an innovative way. My intent here is not to propose or advocate for a particular model of corporate ownership or investment. Not only have a number of scholars already engaged in serious study about this matter, 48 but we also have access to anecdotal information ${ }^{49}$ and we soon will be able to evaluate empirical data gathered from nations like Australia and the United Kingdom where recent reforms enable corporate ownership and investment. ${ }^{50}$ Accordingly, this Article leaves for another day the tasks of offering specific recommendations about a particular course of action for corporations desiring to deliver legal services or proposing a particular set of safeguards that should be put into place. ${ }^{51} \mathrm{I}$ do, however, suggest corporate

Thomas R. Andrews, Nonlawyers in the Business of Law: Does the One Who Has the Gold Really Make the Rules?, 40 HASTINGS L.J. 577, 578-79 (1989). For an argument on the unconstitutionality of licensing requirements, see Larry E. Ribstein, The Death of Big Law, 2010 WIS. L. REV. 749, 806-07 ("The extra costs of legal representation resulting from forcing lawyers to attend law school and pass a bar exam therefore may not be worth the benefits in terms of protecting clients from shoddy or dishonest work. These policy arguments could fuel constitutional challenges to lawyer licensing by raising questions as to the public interest served by the regulation." (later citing Andrew W. Perlman, A Bar Against Competition: The Unconstitutionality of Admission Rules for Out-of-State Lawyers, 18 Geo. J. Legal Ethics 135 (2004); Deborah L. Rhode, Policing the Professional Monopoly: A Constitutional and Empirical Analysis of Unauthorized Practice Prohibitions, 34 STAN. L. REV. 1 (1981))).

48 See discussion infra notes 191-96 and accompanying text.

${ }^{49}$ See, e.g., Steve Mark, Views from an Australian Regulator, 2009 J. Prof. LAW. 45, 63 ("The [New South Wales] experience in regulating incorporation has been positive. Far from being the means by which legal practitioners subvert the ethics of the profession, incorporation can provide lawyers with the incentive to more stringently formalize ethical behavior. I have found that, by and large, [incorporated legal practices] have embraced the systemization of compliance we have introduced, and as a result have reaped the rewards in terms of effective and efficient management.").

50 See discussion infra Part IV.

${ }^{51}$ I do not mean to avoid the seriousness or importance of this inquiry by setting it aside for purposes of this Article. Rather, here, my intent is to focus primarily on the First Amendment analysis relevant to corporate ownership and investment in law practices. Nevertheless, as regulators contemplate the lifting of the Model Rule 5.4 ban on external ownership and investment, they must also deliberate over the nature of safeguards that 
ownership and investment in legal services delivery as a viable solution to address the dire access-to-justice problem facing the United States in the twenty-first century. Furthermore, I rely upon this position to evaluate how a court would likely weigh the state's interest in regulating the legal profession compared to the corporation's interest (and the lawyer's interest, as well as the potential client's interest) in the delivery of legal services.

The Article proceeds as follows: Part II provides an overview of the relevant professional conduct rules, primarily American Bar Association Model Rule 5.4 governing the professional independence of a lawyer, and offers a brief history of the Rule's development. Part III engages in a detailed review of the Supreme Court precedent supporting the corporation's First Amendment right to deliver legal services by investing in and owning law practices. The Article wraps up in Part IV with a summary of proposals for corporate ownership of and investment in law practices, including a brief discussion related to regulatory reforms in Australia and the United Kingdom. I conclude that attorney professional conduct rules must be reformed to permit corporations to finance law practices and deliver legal services-a pragmatic and prudent conclusion given the pervasive unmet need and vast untapped market for legal services in this country. This deregulation has the potential to increase competition, drive down prices, encourage inventive methods for providing legal representation to those who cannot access or afford it, and create new jobs for lawyers.

\section{IN A CITIZENS UNITED WORLD, What REMAINS OF STATE Professional CONDUCT RULES BANNING CORPORATE OWNERSHIP OF LAW FIRMS?}

A collective reading of $N A A C P v$. Button and its progeny, the commercial speech cases including Bates v. State Bar, and the Court's recent decision in Citizens United v. FEC suggests that state professional conduct rules banning corporations from owning and investing in law practices impair important First Amendment interests. The form in which these companies or others should finance law practices, as a matter of sound public policy, remains open to question and debate. In the wake of Citizens United, however, a lift on the state bans against corporate law firm ownership may very well be inevitable.

Attorney professional conduct rules throughout the country prohibit corporations from owning or investing directly in law practices. ${ }^{52}$ While the

should remain for preserving lawyer independence and for protecting client interests. A particularly critical point of inquiry will be to explore the role of the insurance industry, perhaps drawing lessons from the medical care industry as well as from countries like Australia and the United Kingdom, where deregulation of the legal profession is well underway.

52 For a detailed history of the ABA's ban on nonlawyer ownership of law firms, see Edward S. Adams \& John H. Matheson, Law Firms on the Big Board?: A Proposal for 
rules have been upheld by various courts on a few occasions in the context of unauthorized practice, ${ }^{53}$ those decisions occurred in a pre-Citizens United world and did not consider the ownership/investment by corporations into the practices of licensed attorneys for the purpose of facilitating the delivery of legal representation. Setting aside potential benefits or costs associated with corporate financing, if the majority's opinion ${ }^{54}$ in Citizens United means what it says about corporate speech, these blanket bans are problematic in their interference with the corporation's right to own and invest in the delivery of legal services, a right derived from the First Amendment as first recognized by the Court in Button.

The notion of a First Amendment right for corporations to deliver legal services is controversial, to be sure, as is the suggestion that Citizens United might confirm a corporation's right to engage in such a practice. Legal profession scholars and business law experts have written extensively over the years weighing the merits of nonlawyer law practice ownership and investment. ${ }^{55}$ The ink is only beginning to flow about the consequences of Citizens United. ${ }^{56}$ In the months following the decision's release, scholars

Nonlawyer Investment in Law Firms, 86 CALIF. L. REV. 1, 3-11 (1998). See also discussion of state professional conduct rules infra note 64 .

${ }^{53}$ See, e.g., Lawline v. Am. Bar Ass'n, 956 F.2d 1378, 1386-87 (7th Cir. 1992) (holding that Model Rules 5.4(b) and 5.5(b) are rationally related to the legitimate state interests of safeguarding the public, maintaining the integrity of the legal profession, and protecting the administration of justice; no First Amendment violation in prohibiting association of nonlawyers in partnership with lawyers); Turner v. Am. Bar Ass'n, 407 F. Supp. 451 (N.D. Tex. 1975) (finding no violation of non-lawyers' First Amendment rights in ban on partnership between lawyers and nonlawyers). Signficantly, both of these challenges involved practice of law by nonlawyers, not the issue addressed in this Article, namely the delivery of legal services by lawyers through an arrangement involving ownership or investment by a corporation.

54 When referring to the "majority opinion" in Citizens United, I refer to the portions of the opinion authored by Justice Kennedy and joined in concurrence by Chief Justice Roberts and Justices Alito, Scalia, and Thomas. See Citizens United v. FEC, 130 S. Ct. 876, 877 (2010).

${ }^{55}$ Compare Adams \& Matheson, supra note 52, at 1-2 (advocating for the lifting of state restrictions on nonlawyer investment in law firms and suggesting that the benefits to this proposal "include capital for expansion, capital for investment in new technologies and new lawyers, financing for contingency fee cases, and a myriad of other rewards"), with Susan Gilbert \& Larry Lempert, The Nonlawyer Partner: Moderate Proposals Deserve a Chance, 2 Geo. J. Legal ETHICS 383, 392-400 (1988) (noting that debate about reform to Model Rule 5.4 during a February 1983 ABA meeting was essentially shutdown on the socalled "fear of Sears"-i.e., the idea that Sears could own a law firm). See also discussion infra Part IV.

56 See, e.g., Randall P. Bezanson, No Middle Ground? Reflections on the Citizens United Decision, 96 IOWA L. REV. 649, 650 (2010) (suggesting that Justice Kennedy wrote such a "bold-some would say reckless" opinion "to make clear in no uncertain terms that corporations and other forms of organizations are as fully protected by the First Amendment as are individuals"); Richard L. Hasen, Citizens United and the Illusion of Coherence, 109 MiCH. L. REv. 581, 585 (2011) (contending that the "Court's analysis in Citizens United is 
quickly (and critically) weighed in on the potential impact to First Amendment jurisprudence and the political landscape, particularly for federal and state elections. ${ }^{57}$ The decision's influence on the law of lawyering, however, has yet to be identified, let alone fully explained or appreciated. ${ }^{58}$ Commentators speculate about what Citizens United means for business regulations. ${ }^{59}$ This Article, however, is the first to address the opinion's impact on the delivery of legal services by corporations.

Sentiments are strong on both sides of this issue, as portrayed in legal ethics expert Larry Fox's comments a decade ago:

The brashness [of a proposal allowing for corporate law firm ownership] left me weak of knee, my forehead beaded with perspiration, palpitations interrupting my ability to think straight. But then I recovered, recalling my commitment to the ideas that lawyers are not just another set of service

likely to lead to new incoherence in the Court's campaign finance jurisprudence" and assessing "the challenge such incoherence poses for lawyers arguing campaign finance cases in the Supreme Court and lower courts"). For a lengthy list of commentary appearing in the media and blogosphere following the Citizens United decision, see SCOTUSBLOG, $\mathrm{http}: / / \mathrm{www}$.scotusblog.com/case-files/cases/citizens-united-v-federal-election-commission/ (last visited Feb. 1, 2012) (listing over 100 media links and nearly as many blog links).

${ }^{57}$ See, e.g., Floyd Abrams, Citizens United and Its Critics, 120 YALE L.J. ONLINE 77, 78 (2010), http://yalelawjournal.org/images/pdfs/902.pdf (noting the "fury of critics of the [Citizens United] opinion and the fierceness of their criticism" and that "[ $\mathrm{t}] \mathrm{he}$ ruling was treated as a desecration"); Carol R. Goforth, "A Corporation Has No Soul"-Modern Corporations, Corporate Governance, and Involvement in the Political Process, 47 Hous. L. REV. 617, 651-61 (2010) (arguing that Citizens United was wrongly decided both as a matter of original intent and as supported by important public policy reasons).

${ }^{58}$ For one example of scholarship identifying the impact of Citizens United beyond the context of elections, see Tamara R. Piety, Citizens United and the Threat to the Regulatory State, 109 MICH. L. REV. FIRST IMPRESSIONS 16, 16 (2010),

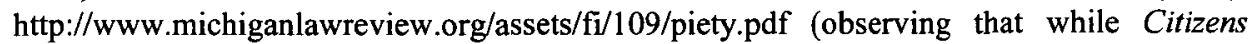
United "has been roundly criticized for its potential effect on elections and its display of judicial immodesty ...., the effect of the case which may be both most profound and perhaps most pernicious is its effect on the commercial speech doctrine[,] ... an aspect of the case which has been largely overlooked"). Significantly, she does not consider the impact on the lawyer advertising/solicitation commercial speech cases that are addressed in this Article.

${ }^{59}$ See, e.g., Bezanson, supra note 56, at 660-61 ("The conferral of full free-speech rights on corporations will likewise require us to consider a host of other settings in which the speech of corporations is now highly regulated. The securities laws, for example, place heavy limits on information published .... The corporation itself, as a form of business or private or charitable organization, is pervasively regulated at the state and federal level.... Full First Amendment protection would likely require dramatic changes in these and related regimes of corporate regulation. Is the Court willing to invite such claims? Nothing in the opinion suggests that they were even considered."). 
providers, that what separates us ... is our commitment to a higher set of values ....60

In contrast, consider the more recent reflections of Bruce MacEwen, a noted specialist in law firm economics, in an exchange with Professors Mitt Regan and Larry Ribstein:

If anyone wants to mount a serious challenge to the ABA's medieval guild mentality [against reforms like corporate ownership of law firms], show me where to sign up. That our industry is the only one which attempts-with a transparent lack of success-to cloak anticompetitive injunctions with the cloth of "ethics" is as humiliating as it is depressing. ${ }^{61}$

Weak in the knees, sweating, humiliated, depressed: regardless of the side one takes, the debate on nonlawyer investment is not for the faint of heart. Proponents maintain that corporate ownership and investment will help liberate legal services by bringing affordable representation to the general population and by addressing the well-documented, unmet need for lawyers. ${ }^{62}$ Opponents counter that corporate involvement will exacerbate the poor reputation of lawyers, compromise lawyer independence, and subject lawyers to insurmountable conflicts of interests driven by a profit motive instead of service to the client. ${ }^{63}$ Neither side, however, seems to appreciate the First Amendment interests inextricably bound up in the debate.

The central rule involved in the debate is ABA Model Rule 5.4. The rule purports to guide the professional independence of a lawyer, and a similar if not identical version has been adopted in all fifty states, with the District of Columbia having a version that allows some forms of multidisciplinary practice, but not external ownership. ${ }^{64}$ Model Rule 5.4 provides, in relevant part, that

${ }^{60}$ Lawrence J. Fox, Dan's World: A Free Enterprise Dream; An Ethics Nightmare, 55 Bus. LAw. 1533, 1534 (2000) (replying to Daniel Fischel's proposal to allow the market to regulate lawyer and nonlawyer involvement rather than professional conduct rules).

${ }^{61}$ Bruce MacEwen, Milton C. Regan, Jr. \& Larry Ribstein, Law Firms, Ethics, and Equity Capital, 21 Geo. J. LegAL ETHICs 61, 61, 86-87 (2008) (discussing the impact of the United Kingdom's Legal Services Act 2007 on American law firms and reflecting on whether "a derivative instrument structured to reflect the implicit value of the firm" violates Model Rule 5.4).

${ }^{62}$ See discussion infra Part IV.

${ }^{63}$ See discussion infra Part IV.

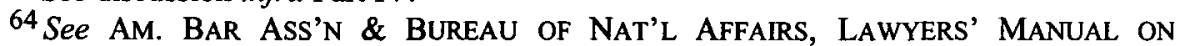
PROFESSIONAL CONDUCT 91:402 (2008) (noting that with one "notable" exception, the Dist. of Columbia, "[m]ost jurisdictions that base their ethics rules on the ABA Model Rules do not deviate appreciably from Rule 5.4(b) and Rule 5.4(d)"). The Lawyers' Manual describes the small variations in the rules of North Carolina, Illinois, Oklahoma, Washington, Florida, Kentucky, Utah, and the Dist. of Columbia. Id. at 91:402-03. While the District of Columbia's rule is more permissive in that it allows for certain forms of multidisciplinary practice, it does not permit a corporation to own or invest in a legal services delivery mechanism. See D.C. RULES OF PROF'L CONDUCT R. 5.4, 5.7 (2007). 
"[a] lawyer or law firm shall not share legal fees with a nonlawyer" and "shall not form a partnership with a nonlawyer if any of the activities of the partnership consist of the practice of law." 65 The rule also states that "[a] lawyer shall not practice with or in the form of a professional corporation or association authorized to practice law for a profit if ... a nonlawyer owns any interest therein" or "a nonlawyer is a corporate director or officer." 66 The ABA's prohibition on nonlawyer investment in law firms extends back to the $1920 \mathrm{~s},{ }^{67}$ though the rule finds its origin in a New York State criminal statute enacted in 1909 at the request of individual lawyers concerned about competition from corporations contracting with lawyers in bulk to provide legal advice to subscribers. ${ }^{68}$

According to the comments for Rule 5.4, the purpose of these restrictions is to help avoid potential interference with a lawyer's professional judgment. 69 The primary justifications advanced in support of the rule are: (1) the preservation of lawyer independence, (2) professionalism and the reputation of the legal profession, and (3) the avoidance of ethical dilemmas that are covered elsewhere in the conduct rules, such as conflicts of interest, client confidentiality, and the lawyer's duties to the client and the court. The ABA Commission on Evaluation of Professional Standards (also known as the Kutak Commission) during the early 1980s considered reforms that would have allowed for nonlawyer investments under certain conditions, but the reforms ultimately were rejected. ${ }^{70}$

As the Restatement notes, however, this rejection was not without costs. Interestingly, and perhaps not surprisingly, the Restatement casts those costs as harms suffered by lawyers:

One cost is that any kind of capital infusion that would entail granting an ownership or security interest in the law firm itself ... to a nonlawyer investor

${ }^{65}$ Model Rules of Prof'L CONDUCT R. 5.4(a), (b) (2011).

${ }^{66} I d$. R. 5.4(d)(1), (2).

${ }^{67}$ See CANONS OF PROF'L ETHICs Canon 33 (1929). For more on the history of the rule, see Adams \& Matheson, supra note 52, at 4-14.

${ }^{68}$ See Bruce A. Green, The Disciplinary Restrictions on Multidisciplinary Practice: Their Derivation, Their Development, and Some Implications for the Core Values Debate, 84 MINN. L. REV. 1115, 1126-28 (2000).

${ }^{69}$ MODEL Rules OF PROF'L CONDUCt R. $5.4 \mathrm{cmt}$. 1; see also RESTATEMENT (THIRD) OF THE LAW GOVERNING LAWYERS $\S 10 \mathrm{cmt}$. b (2000) ("Those limitations are prophylactic and are designed to safeguard the professional independence of lawyers. A person entitled to share a lawyer's fees is likely to attempt to influence the lawyer's activities so as to maximize those fees. That could lead to inadequate legal services."); id. $\S 10 \mathrm{cmt}$. c ("Here also the concern is that permitting such ownership or direction would induce or require lawyers to violate the mandates of the lawyer codes, such as by subjecting the lawyer to the goals and interests of the nonlawyer in ways adverse to the lawyer's duties to a client.").

${ }^{70}$ For a detailed history of the debate within the American Bar Association on multidisciplinary practice, see Charles W. Wolfram, The ABA and MDPs: Context, History, and Process, 84 MINN. L. REV. 1625 (2000); see also Andrews, supra note 47, at 579-600. 
is prohibited. ... [S] uch practical barriers to infusion of capital into law firms significantly limit the ability of law firms to attain what its lawyers may consider to be a more optimal size at which to provide higher-quality and lower-price services to clients. They may also deter law firms from more effectively competing with established law firms and with nonlawyer organizations.... Further, unlike other persons in many... occupations, lawyers are unable to realize the present economic value of their reputations, which otherwise could be obtained through sale to investors of stock or other ownership interest. ${ }^{71}$

Yet, all of the concerns identified by the Restatement ultimately harm the public-not just lawyers-according to Professor Stephen Gillers, because Model Rule 5.4 increases the cost of legal services. The rule does so by "suppress[ing] competition on the supply side. The fewer the consumer alternatives, the more lawyer-employers can charge for their employees' time."72 He sees the rule as "indefensibly lawyer-centered"73 and rejects the justification that it protects clients. ${ }^{74}$ Instead, he observes that "some lawyers benefit and others lose, which is why the rule must be seen as serving the interests of ABA control groups and not lawyers generally."75 Thus, "[a] firm that wants to accept lay investment and predicts it can without ignoring its duties to keep confidences and exercise independent professional judgment may not do so, no matter how persuasive a case it can make in support of its prediction." "76 This protects "[e]stablished firms, with accumulated capital and clientele, ... from the rapid growth of new competitors that private investment might encourage," and hurts newer lawyers, "[b]ecause only other lawyers may hire them to provide legal services to third persons for a profit, [and] the number of these jobs will be limited by the number of lawyers willing to create them."77

Writing over two and a half decades ago, significantly, Gillers predicted that in the absence of Model Rule 5.4, "the number of these jobs [for newer

${ }^{71}$ RESTATEMENT (THIRD) OF THE LAW GOVERNING LAWYERS $\S 10 \mathrm{cmt}$. c. For further discussion of Model Rule 5.4's anti-competitive effect, see Stephen Gillers, What We Talked About When We Talked About Ethics: A Critical View of the Model Rules, 46 OHIO ST. L.J. 243, 266-68 (1985). Professor Gillers argues that Model Rule 5.4 "must be counted as serving the interests of some critical mass of lawyers, numerous and powerful enough" to stop reform and that the rule "exclude[s] a major source of capital for new firms." Id. at 267-68. He notes: "In addition to the predictable downward pressure on fees that would accompany increased competition, lay investors might be willing to accept a lower return on their money." Id. at 268; see also Deborah L. Rhode, Policing the Professional Monopoly: A Constitutional and Empirical Analysis of Unauthorized Practice Prohibitions, 34 STAN. L. REV. 1, 10 (1981).

${ }^{72}$ Gillers, supra note 71 , at $266-68$.

73 Id. at 247.

${ }^{74}$ See id. at 267.

${ }^{75} \mathrm{Id}$. at 268.

${ }^{76} \mathrm{Id}$.

${ }^{77} \mathrm{Id}$. 
lawyers] likely would expand."78 This is surely good news for recent law graduates, facing unprecedented reductions in hiring. Ultimately, the clients are the losers here, says Gillers. ${ }^{79}$ Those allowed to deliver legal services under this rule are able to charge more for their time, and to constrict the number of lawyers available, all to the detriment of the public. ${ }^{80}$

In addition to Model Rule 5.4, other professional conduct rules potentially limit corporate investment in law practices, including rules regarding the unauthorized practice of law, ${ }^{81}$ payment of legal fees by a third party without client consent, ${ }^{82}$ and the ban against the sale of a law firm to nonlawyers. ${ }^{83}$ As Part III will show; to the extent that these rules forbid a corporation from owning or investing in a law practice, it is questionable whether they can withstand a First Amendment challenge, particularly in the wake of Citizens United.

\section{FROM NAACP V. BUTTON TO CITIZENS UNITED V. FEC: ESTABLISHING THE CORPORATION'S FIRST AMENDMENT RIGHT TO DELIVER LEGAL SERVICES Through LAW Practice OWNERShIP/INVESTMENT}

The First Amendment provides, in relevant part, that "Congress shall make no law ... abridging the freedom of speech ... or the right of the people peaceably to assemble, and to petition the Government for a redress of grievances." 84 This protection is made applicable to the states by the Fourteenth Amendment. ${ }^{85}$ The Supreme Court has long extended the protection of the First Amendment to corporations, and the Court recently reaffirmed that this protection is as strong for a company as it is for an individual. 86

${ }^{78}$ Gillers, supra note 71 , at 268 .

${ }^{79} \mathrm{Id}$. (The rule of thumb has been that a law firm associate's time should be billed at a rate that nets a profit of one-third after deduction of salary and overhead. That's a pretty good margin, one other investors might be willing to undersell." (footnote omitted)).

${ }^{80}$ See id.

${ }^{81}$ Model Rule 5.5 provides that a lawyer admitted in one jurisdiction "shall not practice law in a jurisdiction in violation of the regulation of the legal profession in that jurisdiction." MODEL RULES OF PROF'L CONDUCT R. 5.5 (2011).

82 See id. R. 1.8(f).

${ }^{83}$ See id. R. 1.17.

${ }^{84}$ U.S. CONST. amend. I.

85 See id. amend. XIV.

${ }^{86}$ See Citizens United v. FEC, 130 S. Ct. 876, 899 (2010) ("The Court has recognized that First Amendment protection extends to corporations." (listing twenty-two Supreme Court cases dating back to 1952)); see also First Nat'l Bank of Bos. v. Bellotti, 435 U.S. 765,777 (1978) ("The inherent worth of the speech in terms of its capacity for informing the public does not depend upon the identity of its source, whether corporation, association, union, or individual."). 
Historically, courts and the academy devoted scant attention to intersections between the lawyer conduct rules and the First Amendment. ${ }^{87}$ In recent years, however, this has changed somewhat, particularly once the Supreme Court struck down the Arizona state bar rule banning lawyer advertisements. ${ }^{88}$ Nevertheless, the First Amendment's application to rules prohibiting nonlawyer investment in or ownership of law practices remains almost entirely unexplored in academic literature ${ }^{89}$ One notable exception is an article from Professor Gary Munneke, who nearly two decades ago presciently predicted the First Amendment vulnerabilities of state restrictions on law firm diversification for providing ancillary business. ${ }^{90}$ Though he did not expressly contemplate the merits of corporate law practice ownership, his First Amendment discussion bears on the analysis here.

Professor Munneke suggested two approaches for testing "ethical rules that restrict relationships between lawyers and nonlawyers: freedom of association and commercial speech."91 He recognized that both approaches were tenuous, at least under the then-existing state of constitutional law. Munneke cautioned: "Under a First Amendment approach, the freedom of association theory is hampered by the possible application of a rational basis test of the legitimacy of the state's regulatory scheme, while the commercial speech theory is generally understood to apply to advertising rather than other forms of conduct. 92 Nevertheless, he maintained that "[e]thical rules governing conflicts of interests, candor, confidentiality and other matters apply to lawyers in whatever they do, and such rules, if vigorously enforced, are sufficient to protect the interests of clients, individual lawyers and the legal profession," and therefore we do not need bans on external investment or practice. ${ }^{93}$ Not only do these same ethical protections remain today, but as this Article illustrates, the First Amendment vulnerabilities identified by Professor Munneke are significantly diminished given the protection of corporate speech required post-Citizens United.

This Article proposes an alternative to Munneke's approach for testing rules that restrict lawyer relationships with corporations. While I applaud him for

${ }^{87}$ See Knake, supra note 20 , at 660-63 (listing cases and articles addressing the First Amendment and the regulation of attorney speech generally). For a noteworthy exception, see Monroe FreEdman \& ABbe SMith, Understanding LaWYers' ETHICs 333-36 (4th ed. 2010).

${ }^{88}$ See Bates v. State Bar, 433 U.S. 350, 384 (1977); Knake, supra note 20, at 660 (listing advertising and soliciting cases decided by the Supreme Court from 1963 to 2010).

${ }^{89}$ See, e.g., Knake, supra note 20, at 660; Gary A. Munneke, Dances with Nonlawyers: A New Perspective on Law Firm Diversification, 61 FordHAM L. REv. 559, 595 (1992) ("Although this constitutional problem has been alluded to in the recent ABA debates, most commentators have not explored the question fully." (footnote omitted)).

90 See Munneke, supra note 89, at 595.

91 Id.

92 Id. at 614

93 Id. at 615 ("We do not need and can ill-afford archaic nules designed merely to maintain the economic hegemony of the legal profession, especially when those rules have become counterproductive to their original purpose."). 
recognizing the issue, I have a somewhat different view of the Court's jurisprudence on lawyer speech, at least in the context of legal services delivery. Rather than applying a separate method of First Amendment analysis to each category of speech as he does, a collective analysis of the cases (viewed with the hindsight of Citizens United) establishes that corporate activity "undertaken to obtain meaningful access to the courts is a fundamental right within the protection of the First Amendment," a right deserving of strong protection, as the Court observed in United Transportation Union $v$. State Bar, discussed more fully below. ${ }^{94}$ For now, what is essential to understand is that the Court's recognition that the First Amendment protects "meaningful access" to legal advice is really about the delivery of legal services, i.e., meaningful access is achieved through meaningful delivery.

This "meaningful access" speech interest-i.e., what I equate with the delivery of legal services-is bound up in the freedoms of speech, assembly, and petition established in Button. This interest also extends to recipients of the meaningful access speech, including individuals, the public, and the judiciary. The Court has observed that under the First Amendment, "the protection afforded is to the communication, to its source and to its recipients both."95 This includes a constitutional "right to receive information and ideas." 96 For example, in the attorney advertising cases (discussed more fully below), the Court recognized the legal rights of the targeted recipients of the speech, the potential clients, and the public as a whole. ${ }^{97}$ This is true, said the Court, even if the recipient's choice ultimately is undesirable:

To be sure, some citizens, accurately informed of their legal rights, may file lawsuits that ultimately turn out not to be meritorious. But the State is not entitled to prejudge the merits of its citizens' claims by choking off access to

94401 U.S. 576, 585 (1971) (emphasis added).

95 Va. State Bd. of Pharmacy v. Va. Citizens Consumer Council, Inc., 425 U.S. 748, 756 (1976) (holding that a statutory ban on advertising drug prices for prescription drugs violated the First and Fourteenth Amendments).

${ }^{96}$ Id. at 757 (internal quotation marks omitted); see also State ex rel. Okla. Bar Ass'n v. Porter, 766 P.2d 958, 967 (Okla. 1988) ("It is well established that the [C]onstitution protects the right to receive information and ideas. The right of the public to receive suitable access to social, political, esthetic, moral, and other ideas and experiences is crucial, for it is the purpose of the First Amendment to preserve an uninhibited marketplace of ideas in which truth will ultimately prevail.").

${ }^{97}$ For example, in Virginia State Board of Pharmacy, the Court held unconstitutional a state statute prohibiting pharmacists from advertising prescription drug prices, thus opening the door to First Amendment protection for professional commercial speech. 425 U.S. at 757. To justify establishing this new protected category, the Court explained, "As to the particular consumer's interest in the free flow of commercial information, that interest may be as keen, if not keener by far, than his interest in the day's most urgent political debate." Id. at 763 . The Court extended the protection to the commercial speech of attorneys in Bates v. State Bar, 430 U.S. 350,384 (1977). 
information that may be useful to its citizens in deciding whether to press those claims in court. ${ }^{98}$

There are at least three components to the notion that the First Amendment protects meaningful access to the law with respect to the delivery of legal services by corporations. First, the First Amendment's protections extend to corporations as a potential source of speech and information about the law. Second, the First Amendment right also includes the recipient's entitlement to hear the speech and information about the law. Third, this dual right between speaker and hearer exists even if it is exercised imprudently.

Consider the value of legal advice to the listener or recipient from a public policy angle. According to Professor Stephen Pepper, "law is a public good that is intended to be available for individuals to use in leading their lives.... This means that a client has a clear interest in, and perhaps even an entitlement to, knowledge of the law that governs her." 99 He goes so far as to connect the client's interest in legal advice and advocacy directly with political and democratic values: "our democratic constitutional order presumes that persons do have something approaching a 'right' to know 'the law' that purports to govern them." 100

Another commentator has offered public policy reasons that reveal the wisdom of these cases. If it is true, as First Amendment scholar Martin Redish observes, that the "fundamental, positive value of the constitutional free speech guarantee is furtherance of individual self-realization,"101 then it follows that knowledge of the law is imperative for securing "the individual's ability and opportunity to make all levels of life-affecting decisions, thereby controlling and determining her life's course."102 It thus becomes clear that the recipient's right to meaningful access speech produced through the delivery of legal services by a corporation is equally as important (if not even more important) to the First Amendment as the corporation's right to deliver those services.

Let us now turn to a detailed discussion of the thread of Supreme Court opinions establishing the nonlawyer corporation's First Amendment right to engage in activity with lawyers to provide meaningful access to the law or, in other words, to deliver legal services. This line of cases-from Button to Citizens United-reveals the critical First Amendment interests held not only by

${ }^{98}$ Zauderer v. Office of Disciplinary Counsel, 471 U.S. 626, 645 n.12 (1985); see also Scanlon, supra note 8, at 222-24 (advancing an approach that would protect the listener-in this case the client-by prohibiting government from banning speech-in this case an attorney's advice--because it might influence the client).

${ }^{99}$ Stephen L. Pepper, Counseling at the Limits of the Law: An Exercise in the Jurisprudence and Ethics of Lawyering, 104 YALE L.J. 1545, 1598-99 (1995).

${ }^{100}$ Id. at 1599.

101 MarTin H. REDish, MONEY TAlKS: SPEeCh, ECONOMIC POWER, AND THE VAlues OF DEMOCRACY 71 (2001).

${ }^{102}$ Id. 
corporations, but also individuals, lawyers, the judiciary, and the public generally.

\section{A. The First Amendment Value in the Delivery of Legal Services and NAACP v. Button}

First Amendment protection for the delivery of legal services by a corporation stems from the 1963 decision NAACP v. Button, ${ }^{103}$ where the Supreme Court held that states could not ban the delivery of legal services through an arrangement involving the NAACP (a nonprofit corporation), ${ }^{104}$ its affiliates, and lawyers. ${ }^{105}$ Specifically, the Court examined "the right of the NAACP and its members and lawyers to associate for the purpose of assisting persons who seek legal redress for infringements of their constitutionally guaranteed and other rights." 106 While framed in the context of the First Amendment's protections for assembly and petition of the government, much of the Court's opinion also rests upon the Free Speech Clause. The majority held that the First Amendment protects advice from NAACP attorneys to prospective litigants about seeking legal assistance, notwithstanding the Commonwealth's power to regulate the legal profession and improper solicitation of legal business. ${ }^{107}$ As Professor Munneke says, "[A]t the heart of the case was the mechanism for the delivery of legal services."108 Similarly, Professor William Eskridge characterizes Justice Brennan's treatment of the NAACP "as an advocacy corporation having First Amendment rights of its own."109 The Court also recognized the political value inherent in legal advocacy, for "[g]roups which find themselves unable to achieve their objectives through the ballot frequently turn to the courts.... And under the conditions of modern government, litigation may well be the sole practicable avenue open to a minority to petition for redress of grievances." 110 Moreover, the Court acknowledged and protected the interests of individuals in receiving the legal advice and advocacy services, as well as the attorneys' interests in providing representation. ${ }^{111}$ In short, Button stands for the proposition that the First

103371 U.S. 415 (1963).

104 Id. at 419 ("The NAACP was formed in 1909 and incorporated under New York law as a nonprofit membership corporation in 1911.").

105 Id. at 429.

106 Id. at 428 .

${ }^{107} \mathrm{Id}$. at 438 ("[O]nly a compelling state interest in the regulation of a subject within the State's constitutional power to regulate can justify limiting First Amendment freedoms."); $i d$. ("Precision of regulation must be the touchstone in an area so closely touching our most precious freedoms."); see also Knake, supra note 20, at 665 (arguing that Button establishes First Amendment protection for the advice an attorney renders to her client).

${ }^{108}$ Munneke, supra note 89, at 604.

${ }^{109}$ William N. Eskridge, Jr., Some Effects of Identity-Based Social Movements on Constitutional Law in the Twentieth Century, 100 MiCH. L. REV. 2062, 2336 (2002).

110 Button, 371 U.S. at 429-30 (footnotes omitted).

111 Id. at 434-35. 
Amendment protects the delivery of legal services through an arrangement between a nonprofit corporation and lawyers.

The Court extended the holding of Button to situations beyond the civil rights context in a series of three cases involving unions. The first was Brotherhood of Railroad Trainmen v. Virginia ex rel. Virginia State Bar. ${ }^{112}$ There, the Court declared that an injunction prohibiting the Brotherhood from advising injured workers to obtain legal advice violated the First Amendment. ${ }^{113}$ The Court protected the lawyers' rights to speak as well as the prospective clients' rights to hear. ${ }^{114}$ Again, as Professor Munneke notes, like Button, "an innovative service delivery system was upheld despite the arrangement's violation of ethical rules. In fact, Trainmen dealt specifically with a practice delivery system involving both lawyers and nonlawyers."115 In United Mine Workers, District 12 v. Illinois State Bar Ass' $n,{ }^{16}$ the Court clarified that Button was not meant to be limited solely to political litigation and struck another injunction brought by a state bar organization to prohibit a union from hiring an attorney to advise members in processing workers' compensation claims." The Court held "that the freedom of speech, assembly, and petition guaranteed by the First and Fourteenth Amendments gives ... the right to hire attorneys ... to assist ... in the assertion of ... legal rights."118 Several years later the Court reaffirmed Button in United Transportation Union $v$. State Bar, observing that "meaningful access to the courts is a fundamental right within the protection of the First Amendment."1 19

The union cases build upon Button in three important ways. First, they clarify that the First Amendment protects legal advice and advocacy not only about political and civil rights, but also about other matters. Second, they suggest that the First Amendment protects a legal services delivery system involving nonprofit corporations, nonlawyers, and lawyers. Third, while Button and the union cases focused on whose rights were at stake (i.e. the First

112377 U.S. 1 (1964).

${ }^{113} \mathrm{Id}$. at 7 ("A State could not, by invoking the power to regulate the professional conduct of attorneys, infringe in any way the right of individuals and the public to be fairly represented in lawsuits authorized by Congress to effectuate a basic public interest. Laymen cannot be expected to know how to protect their rights when dealing with practiced and carefully counseled adversaries ....").

114 Id.

115 Munneke, supra note 89, at 604 (citation omitted).

116389 U.S. 217 (1967).

${ }^{117}$ Id. at 223 ("The litigation in question is, of course, not bound up with political matters of acute social moment, as in Button, but the First Amendment does not protect speech ... only to the extent it can be characterized as political. Great secular causes, with small ones, are guarded. The grievances for redress of which the right of petition was insured, and with it the right of assembly, are not solely religious or political ones. And the rights of free speech and a free press are not confined to any field of human interest." (internal quotation marks omitted)).

${ }^{118}$ Id. at 221-22 (footnote omitted).

119410 U.S. 576,585 (1971). 
Amendment protection of the lawyers' rights to speak and of the prospective clients' rights to hear) these cases also protected what was being said (i.e. the First Amendment protection of legal advice). Another case that builds upon Button in a consequential way for purposes here is Legal Services Corp. $v$. Velazquez. ${ }^{120}$

\section{B. Legal Advocacy/Advice as Protected Speech and Legal Services Corp. v. Velazquez}

In Velazquez, a 5-4 majority struck, on First Amendment grounds, a federal restriction that prevented attorneys for the Legal Services Corporation (LSC) (a congressionally created nonprofit organization providing legal assistance in civil matters) from challenging the validity of a state or federal statute. ${ }^{121}$ Under the challenged restriction, the LSC attorneys were required to cease representation immediately if a question about a statute's validity arose, whether "during initial attorney-client consultations or in the midst of litigation proceedings." 122

Justice Kennedy, writing for the majority, raised several concerns tied to the First Amendment about this predicament. First, he observed that the legislative restriction prevented attorneys not only from advising clients, but also from advising a court about "serious questions of statutory validity." 23 Such an arrangement, Kennedy wrote, "is inconsistent with the proposition that attorneys should present all the reasonable and well-grounded arguments necessary for proper resolution of the case." 124 Second, a ban on "the analysis of certain legal issues" in effect "prohibits speech and expression upon which courts must depend for the proper exercise of the judicial power." 125 Third, the arrangement, he observed, "insulate[s] the Government's laws from judicial

${ }^{120}$ See 531 U.S. 533, 549 (2001) (holding that the federal government's prohibition against challenging the validity of welfare laws, by attorneys working for a congressionally created legal aid organization, is a violation of the First Amendment).

${ }^{121}$ See id. at 536-37 ("[T] recipients of LSC moneys if the representation involves an effort to amend or otherwise challenge existing welfare law."). Justices Kennedy, Breyer, Ginsburg, Stevens, and Souter formed the majority. Justice Scalia filed a dissenting opinion, in which Chief Justice Rehnquist and Justices O'Connor and Thomas joined. See id. at 549 (Scalia, J., dissenting). The particular restriction under dispute "prevent[ed] an attorney from arguing to a court that a ... state or federal statue by its terms or in its application is violative of the United States Constitution." Id. at 537 (majority opinion). It should be noted that other LSC restrictions on lobbying, class actions, attorney's fees, and solicitation have been upheld in the lower courts. See, e.g., Legal Aid Servs. of Or. v. Legal Servs. Corp., 608 F.3d 1084, 1087 (9th Cir. 2010) (upholding "restrictions on lobbying, soliciting clients, and participating in class actions").

122 Velazquez, 531 U.S. at 545.

123 Id.

${ }^{124}$ Id.

125 Id. 
inquiry." 126 Finally, Justice Kennedy expressed concern that, if the legislative restriction was validated by the Court, "there would be lingering doubt whether the truncated representation had resulted in . . . full advice to the client." 127 As a consequence both " $[\mathrm{t}] \mathrm{he}$ courts and the public" would be left "to question the adequacy and fairness of professional representations when the attorney ... avoided all reference to questions of [the banned advice]." 128 In recognizing the importance of "an informed, independent bar," 29 he further noted that "[w]e must be vigilant when Congress imposes rules and conditions which in effect insulate its own laws from legitimate judicial challenge."130

The ban on delivery of legal services by corporations (through the ownership of law practices) raises the same kinds of constitutional concerns as the ban struck down by the Court in Velazquez. Justice Kennedy went to great lengths to explain the importance of legal speech (i.e., advice and advocacy) to the judiciary and to democratic government. Preventing corporations from entering the legal services market silences a significant source of legal advice and advocacy. ${ }^{131}$ The judiciary, itself, has a strong First Amendment interest in this speech, as it is a critical listener in the process of legal service delivery. ${ }^{132}$ Rules that impair the range or amount of legal advice and advocacy that might reach the judiciary unconstitutionally burden the First Amendment.

Notwithstanding the holdings of Button and the union cases, as well as Velazquez, courts and commentators limit the reach of these decisions because they did not involve for-profit corporations, and thus did not present the concern that a lawyer's loyalty to a client might be compromised by pressure to increase profits to satisfy corporate executives or shareholders. ${ }^{133}$ After Citizens United, this rationale no longer holds up. Before exploring the impact of Citizens United, however, it is important to consider the Court's commercial speech jurisprudence, particularly the lawyer advertising cases. For even if the Court declines to treat legal advice and advocacy speech like political speech and instead accords it only traditional commercial speech protection, bans on

126 Id. at 546.

${ }^{127} \mathrm{Id}$.

128 Velazquez, 531 U.S. at 546.

$129 \mathrm{Id}$. at 545 .

${ }^{130}$ Id. at 548; see also Hill v. Colorado, 530 U.S. 703, 787 (2000) (Kennedy, J., dissenting) ("Laws punishing speech which protests the lawfulness or morality of the government's own policy are the essence of the tyrannical power the First Amendment guards against.").

${ }^{131}$ Special thanks to Mae Kuykendall for reminding me to think about the implications of Velazquez in this context, and the impact on the availability of legal advice as well as advocacy if corporations are not permitted to fund and/or deliver legal services. For an expanded argument on the implications of Velazquez and First Amendment protection for legal advice, see generally Knake, supra note 20.

${ }^{132}$ I thank Mae Kuykendall and David Udell for reminding me to consider the judiciary's free speech interests.

133 See cases cited supra note 53. 
corporate investment into law practices are likely to fail under Central Hudson. ${ }^{134}$

\section{The Commercial Speech Cases and Bates v. State Bar}

Commercial speech jurisprudence, particularly the line of cases on lawyer advertising, endorses the notion of a corporation's right to own and invest in law practices (and the corresponding rights of recipients of the speech that results from such a relationship). The Court consistently has rejected the state's proffer of professionalism and lawyer independence as grounds for suppressing truthful information ${ }^{135}$ about legal services, in part based upon the lawyer's speech interest in communicating about her services but equally (if not mostly) based upon the listener's interest in hearing speech about legal services. Traditionally the Court has claimed, at least in form, to scrutinize commercial speech restrictions on an intermediate level, something less than political speech's strict scrutiny but requiring more from Congress or the states than a rational basis to justify a speech regulation. The test requires that "[i]f the communication is neither misleading nor related to unlawful activity, the ... State must assert a substantial interest to be achieved by restrictions on commercial speech."136

Yet, the line between commercial speech and political speech is blurry, especially when it comes to commercial speech about meaningful access to the law. "Access-to-the-law" or "delivery-of-legal-services" speech in many ways serves the same function as political speech. Much of the information about enforcement of legal rights and entitlements is increasingly delivered via a commercial process, in part because of technological advances and in part because of the associated costs. ${ }^{137}$ But does the speech, which is afforded the highest level of constitutional protection in Button, lose some of that protection if it is delivered through a commercial mechanism? Surely not, at least

${ }^{134}$ See infra notes $155-56$ and accompanying text.

135 On the value of "informational function" to the First Amendment, see Ronald K.L. Collins \& David M. Skover, Commerce \& Communication, 71 TEX. L. REV. 697, 730 (1993). Collins and Skover have written that "[t]his 'informational function' is central to the Court's approval of commercial expression as a form of protected speech." Id. (citing Cent. Hudson Gas \& Elec. Corp. v. Pub. Serv. Comm'n, 447 U.S. 557, 563 (1980)). They further explain that, "of the major commercial speech cases in which governmental regulation has been invalidated, nearly all 'involved restrictions on either purely or predominantly informational speech, such as the bans on price advertising.' By comparison, governmental regulations were sustained in cases not involving 'predominantly informational advertising." Collins \& Skover, supra, at 730 (footnote omitted) (quoting Daniel Hays Lowenstein, "Too Much Puff": Persuasion, Paternalism, and Commercial Speech, 56 U. CIN. L. REV. 1205, 1229 (1988)).

136 Cent. Hudson, 447 U.S. at 564.

${ }^{137}$ See, e.g., REDISH, supra note 101, at 2 ("In light of modern economic realities and the structure of modern communications, expression often requires significant financial resources in order to be effective."). 
according to Justice Blackmun, who wrote in his pre-argument memorandum in Bigelow v. Virginial 138 that "[c]ommercial speech is not per se more lowly than other forms." 139 The Court reinforced this stance in 44 Liquormart, Inc. $v$. Rhode Island, where Justice Stevens (joined by Justices Kennedy and Ginsburg) noted that "[ $\mathrm{t}] \mathrm{he}$ mere fact that messages propose commercial transactions does not in and of itself dictate the constitutional analysis that should apply to decisions to suppress them."140 Indeed, "complete speech bans," like the bans on corporate ownership of law practices, "are particularly dangerous because they all but foreclose alternative means of disseminating certain information."'141

The public's interest in receiving or hearing information is a driving force in First Amendment jurisprudence. In the mid-1970s, the Supreme Court first held that advertising about a medical procedure is protected speech under the First Amendment in Bigelow, ${ }^{142}$ and soon thereafter extended the holding to prescription drug advertising in Virginia State Board of Pharmacy v. Virginia Citizens Consumer Council, Inc., ${ }^{143}$ and then to lawyer advertising in Bates $v$. State Bar. ${ }^{144}$ In all of these cases, central to the Court's reasoning was the public's interest in access to information. ${ }^{145}$ That the speech includes an element of financial gain does not mean the State is "free of constitutional constraint."146 Notably, the Court considered not only the interests of the

138421 U.S. 809 (1975).

${ }^{139}$ LINDA GREENHOUSE, BECOMING JUSTICE BLACKMUN: HARRY BLACKMUN'S SUPREME COURT JOURNEY 117 (2005) (internal quotation marks omitted).

140517 U.S. 484, 501 (1996). As a point of clarification, I note that Justice Stevens delivered the opinion of the Court with respect to Parts I, II, VII, and VIII; an opinion with respect to Parts III and V in which Justices Kennedy, Souter, and Ginsburg joined; an opinion with respect to Part VI in which Justices Kennedy, Thomas, and Ginsburg joined; and an opinion with respect to Part IV, where the language quoted above appears, in which Justices Kennedy and Ginsburg joined. Id. at 488-89.

$141 \mathrm{Id}$. at 501 .

142421 U.S. at 829.

143425 U.S. 748,770 (1976).

144433 U.S. 350,384 (1977).

145 See, e.g., Bigelow, 421 U.S. at 822 ("The advertisement ... did more than simply propose a commercial transaction. It contained factual material of clear 'public interest."'). As Justice Blackmun wrote in his pre-argument memorandum for Virginia Pharmacy, "The emphasis in Bigelow was on the public and its right to receive information." GREENHOUSE, supra note 139, at 119 (internal quotation marks omitted). This emphasis remains a concern in the modern commercial speech cases, as discussed throughout this Part.

${ }^{146}$ Bigelow, 421 U.S. at 818 ("The State was not free of constitutional restraint merely because the advertisement involved sales or 'solicitations,' or because appellant was paid for printing it, or because appellant's motive or the motive of the advertiser may have involved financial gain." (citations omitted)); see also Va. Pharmacy, 425 U.S. at 761 ("It is clear ... that speech does not lose its First Amendment protection because money is spent to project it, as in a paid advertisement of one form or another. Speech likewise is protected even though it is carried in a form that is 'sold' for profit, and even though it may involve a solicitation to purchase or otherwise pay or contribute money." (citations omitted)). 
individuals targeted by the advertising, but also of "those with a general curiosity about, or genuine interest in, the subject matter or the law of another State and its development, and to readers seeking reform." 147 The Court focused heavily on the fact that " $\mathrm{t}] \mathrm{he}$ policy of the First Amendment favors dissemination of information and opinion."148 Accordingly, it follows that there is a "First Amendment right to receive information and ideas, and that freedom of speech necessarily protects the right to receive [this information]."149

Reflecting on the recipient's interest in the speech, whether that recipient is an individual, the public as a whole, or a particular entity such as the judiciary, reveals why the commercial speech versus political speech distinction is so easily blurred. Indeed, as the Virginia Pharmacy Court observed, a recipient's interest in commercial information "may be as keen, if not keener by far, than his interest in the day's most urgent political debate."150

The paternalistic nature of the state restrictions also troubled the Virginia Pharmacy Court. For example, in rejecting independence and professionalism as a justification for a ban on advertising, the Court was especially concerned that the "[s]tate's protectiveness of its citizens rests in large measure on the advantages of their being kept in ignorance."151 As commentators note, keeping citizens in ignorance "is as threatening to core democratic values as the suppression of any speaker." 152 The better alternative to paternalism for the Court "is to assume that this information is not in itself harmful, that people will perceive their own best interests if only they are well enough informed, and that the best means to that end is to open the channels of communication rather than to close them." 153 In the end, "[i]f they are truly open, nothing prevents the 'professional' pharmacist from marketing his own assertedly superior product, and contrasting it with that of the low-cost, high-volume prescription drug retailer,"154 just as nothing prevents traditional law firms from offering their services and contrasting them with those offered by a law firm owned by a corporation.

This is true, said the Court later in Central Hudson, "[e]ven when advertising communicates only an incomplete version of the relevant facts, [for] the First Amendment presumes that some accurate information is better than no

147 Bigelow, 421 U.S. at 822.

148 Id. at 829.

149 Va. Pharmacy, 425 U.S. at 757 (internal quotation marks omitted).

150 Id. at 763 .

${ }^{151}$ Id. at 769; see also 44 Liquormart, Inc. v. Rhode Island, 517 U.S. 484, 503 (1996) ("The First Amendment directs us to be especially skeptical of regulations that seek to keep people in the dark for what the government perceives to be their own good.").

${ }^{152}$ Martin H. Redish \& Abby Marie Mollen, Understanding Post's and Meiklejohn's Mistakes: The Central Role of Adversary Democracy in the Theory of Free Expression, 103 NW. U. L. REV. 1303, 1337 (2009).

153 Va. Pharmacy, 425 U.S. at 770.

154 Id. 
information at all."155 Thus, even under Central Hudson's commercial speech intermediate-type test, state bans on corporate investment in law practices necessarily fail, because " $[\mathrm{t}]$ he regulatory technique may extend only as far as the interests it serves. The State cannot regulate speech that poses no danger to the asserted state interest, nor can it completely suppress information when narrower restrictions on expression would serve its interest as well."156 The Court's lawyer-advertising precedent offers a useful illustration.

Striking state bans on corporations from owning or investing in law practices would not be the first instance of such a sweeping action related to the regulation of lawyers. The Justices took a similar path in Bates, finding unconstitutional Arizona's ban on advertising by lawyers. ${ }^{157}$ At the time, lawyer advertising was not allowed under the Model Rules, just like the modern ban on law practice ownership/investment by nonlawyer corporations. "Even though economic considerations were involved in Bates," notes Professor Munneke, "the seminal issue involved the free expression of an idea about the nature of the practice of law that could not be given force without violating the disciplinary rule."158 According to Munneke, "The same expressive value appears in the ABA debate, in the statements of the ancillary business proponents."159 "In fact," Munneke explains,

the political nature of the debate, the forum in which the ideas are being discussed, and the process by which compromise has been achieved lead inexorably to the conclusion that this is the very type of robust debate on issues of public concern that the First Amendment seeks to foster. ${ }^{160}$

Munneke's argument about the expressive value and political nature of the debate on ancillary business restrictions is equally, if not more, compelling in the context of corporate ownership of law practices. The First Amendment value associated with corporate ownership, however, extends far beyond the semantics of the debate. Ownership and investment from corporations promises competition in the legal marketplace as well as increased capital and funding for meritorious litigation. ${ }^{161}$ Under the reasoning of Button, ${ }^{162}$ significant First Amendment value is drawn from enhanced opportunities for affordable, accessible legal representation where otherwise a right might go unenforced or a wrong might go unaddressed.

Another parallel between the ban on corporate ownership and the ban on lawyer advertising is the professionalism justification sometimes advanced in

${ }^{155}$ Cent. Hudson Gas \& Elec. Corp. v. Pub. Serv. Comm'n, 447 U.S. 557, 562 (1980).

156 Id. at 565 (citation omitted).

157 See Bates v. State Bar, 433 U.S. 350, 384 (1977).

158 Munneke, supra note 89 , at 602 .

${ }^{159} \mathrm{Id}$.

${ }^{160} \mathrm{Id}$. at 602 n.290.

161 See discussion infra Part IV.

162 See discussion supra Part III.A. 
support of the ban on external investment. As the Bates Court noted, "[T]he ban on advertising originated as a rule of etiquette and not as a rule of ethics."163 Authoring the majority opinion, Justice Blackmun explained:

Early lawyers in Great Britain viewed the law as a form of public service, rather than as a means of earning a living, and they looked down on 'trade' as unseemly. Eventually, the attitude toward advertising fostered by this view evolved into an aspect of the ethics of the profession. ${ }^{164}$

The majority found noteworthy the fact that the British view about advertising seemed to be changing at the time Bates was argued, ${ }^{165}$ just as now the British view about law practice ownership and investment by corporations undoubtedly is changing in light of the 2007 adoption of the Legal Services Act allowing for nonlawyer ownership. ${ }^{166}$ The Bates majority rejected the Arizona State Bar's "adverse-effect-on-professionalism" argument, stating that "we find the postulated connection between advertising and the erosion of true professionalism to be severely strained." 167 So, too, it is with the debate about corporations and the delivery of legal services. Some believe corporate delivery of legal services will harm professionalism and the reputation of lawyers. Others maintain that the failure to permit corporate delivery of legal services has fueled not only the public disillusionment identified in Bates but also the lack of access to affordable legal representation.

${ }^{163}$ Bates v. State Bar, 433 U.S. 350, 371 (1977); see also Nat Stem, Commercial Speech, "Irrational" Clients, and the Persistence of Bans on Subjective Lawyer Advertising, 2009 BYU L. REV. 1221, 1252 (noting that the Court routinely invalidates "commercial speech restrictions on the basis of the state's condescending estimate of the capacities of its citizens").

${ }^{164}$ Bates, 433 U.S. at 371 (footnote omitted) (citing HENRY S. DRINKER, LEGAL ETHICS 210-11 (1953)).

165 Id. at 371 n.24 ("The British view may be changing. An official British Commission recently presented reports to Parliament recommending that solicitors be permitted to advertise.").

166 See discussion of the United Kingdom's Legal Services Act of 2007 infra notes 22641 and accompanying text.

${ }^{167}$ Bates, 433 U.S. at 368 . As Justice Blackmun wrote, "[T]he assertion that advertising will diminish the attorney's reputation in the community is open to question. Bankers and engineers advertise, and yet these professions are not regarded as undignified." Id. at 369-70 (footnote omitted). "In fact," he continued, "it has been suggested that the failure of lawyers to advertise creates public disillusionment with the profession." Id. at 370 (citing MONROE H. FREEDMAN, LAWYERS' ETHICS IN AN ADVERSARY SYSTEM 115-16 (1975)). The majority further noted:

The absence of advertising may be seen to reflect the profession's failure to reach out and serve the community: Studies reveal that many persons do not obtain counsel even when they perceive a need because of the feared price of services or because of an inability to locate a competent attorney.

Id. at 370 (footnote omitted). 
The Bates majority similarly rejected arguments from the Arizona State Bar about the "adverse effect on the administration of justice" that are relevant to the corporate ownership debate. 168 Just as some suggest that corporate ownership or investment might increase litigation, "[a]dvertising is said to have the undesirable effect of stirring up litigation." 169 Yet this factor did not trouble the majority: "Although advertising might increase the use of the judicial machinery, we cannot accept the notion that it is always better for a person to suffer a wrong silently than to redress it by legal action."170 Furthermore, the Court was concerned about the "burden to access on legal services."171 The ban on corporate ownership is susceptible to this criticism as well. Justice Blackmun concluded that "[a] rule allowing restrained advertising would be in accord with the bar's obligation to facilitate the process of intelligent selection of lawyers, and to assist in making legal services fully available."172 The same logic applies to "restrained" ownership of law practices by corporations. ${ }^{173}$

As Martin Redish has written, "Just as respected theorists have asserted that political speech facilitates the process of self-government by making the individual a more informed voter, so, too, does commercial speech facilitate the process of private self-government, by making individuals better informed in making private life-affecting choices."174 In Redish's view, "[b]oth types of expression, then, foster the same free speech value because both promote and inform the exercise of self-governing decision making." 175 As such, "both forms of expression facilitate the fundamental democratic values of selfdetermination and self-realization."176

If political speech and commercial speech should be protected in the way Redish advocates, then why not speech that furthers meaningful access to the law by facilitating enhanced alternatives of legal services delivery? Consider also the freedom of the press. ${ }^{177} \mathrm{~A}$ regulation banning corporations from owning or investing in newspapers or media companies is unthinkable under the

${ }^{168} \mathrm{Id}$. at $375-76$.

169 Id. at 375 .

170 Id. at 376 .

171 Id. at 376-77.

172 Id. at 377 (internal quotation marks omitted).

173 Also relevant to corporate ownership of law firms is another argument rejected by the Bates Court: the "undesirable economic effects of advertising." See Bates, 433 U.S. at 377. Justice Blackmun countered that "[i]t is entirely possible that advertising will serve to reduce, not advance, the cost of legal services to the consumer." Id. As for the argument that the quality of legal services would suffer when lawyers advertise, Blackmun observed that "[r]estraints on advertising ... are an ineffective way of deterring shoddy work. An attorney who is inclined to cut quality will do so regardless of the rule on advertising." Id. at 378.

${ }^{174}$ REDISH, supra note 101 , at 19 (footnote omitted).

175 Id.

${ }^{176}$ Id. But see generally Robert C. Post, Viewpoint Discrimination and Commercial Speech, 41 LoY. L.A. L. REV. 169 (2007) (writing in response to Redish).

${ }^{177}$ I credit Ronald K.L. Collins with the suggestion that I consider the analogy of the corporation's relationship to the press. 
First Amendment given the centrality of the press to our democratic government. How are regulations banning corporations from owning or investing in law practices any different, given the equally central role of lawyers' advice and advocacy in our democratic government? ${ }^{178}$

Over thirty years after Bates, concerns about the cost of legal services and the availability of affordable, competent attorneys persist, ${ }^{179}$ intensified by recent economic distress. ${ }^{180}$ Professional conduct rules prohibiting corporations from owning or investing in law practices impair meaningful access to the courts and compromise the delivery of information about legal rights and their enforcement. ${ }^{181}$ They raise precisely the same concerns warranting constitutional protection in Button and the lawyer advertising cases that since have followed.

\section{Ohralik v. Ohio State Bar Ass'n and In re Primus}

Two other lawyer-solicitation cases deserve mention. In 1978, the Court decided Ohralik v. Ohio State Bar Ass ' $n^{182}$ and In re Primus ${ }^{183}$ on the same day. In Ohralik, the Court determined that the state could ban an ambulance chaser from in-person solicitation, ${ }^{184}$ but in Primus the Court held that the state could not ban an ACLU lawyer from informing potential litigants about their constitutional rights. ${ }^{185}$ One might reconcile these decisions by looking to the fact that Ohralik solicited for pecuniary gain, ${ }^{186}$ whereas the ACLU lawyer

${ }^{178}$ As I have written elsewhere, "The role of an attorney in navigating and, when necessary, challenging the law is a critical component of American democratic government." Knake, supra note 20, at 642-43.

${ }^{179}$ These concerns are reflected in the dissent authored by Justice Kennedy and joined by Justices Stevens, Souter, and Ginsburg in Florida Bar v. Went For It, Inc., 515 U.S. 618, 642-44 (1995) (Kennedy, J., dissenting). Cf. FREEDMAN \& SMITH, supra note 87, at 333-36 (discussing Went For It and other post-Bates cases).

${ }^{180}$ See, e.g., John T. Broderick Jr. \& Ronald M. George, Op-Ed., A Nation of Do-ItYourself Lawyers, N.Y. TIMES, Jan. 2, 2010, at A21 ("As the economy has worsened, the ranks of the self-represented poor have expanded. In a recent informal study conducted by the Self-Represented Litigation Network, about half the judges who responded reported a greater number of pro se litigants as a result of the economic crisis. Unrepresented litigants now also include many in the middle class and small-business owners who unexpectedly find themselves in distress and without sufficient resources to pay for the legal assistance they need."); Gillian Hadfield, A Case for Legal Aid at Wal-Mart, WASH. POST, Mar. 12, 2010 , at A17 ("Americans have a much higher rate of simply giving up in the face of legal difficulties, with effectively nowhere to turn if they cannot afford a lawyer who comes at a minimum price of $\$ 150$ an hour.").

181 See discussion infra Part IV.

182436 U.S. 447 (1978).

183436 U.S. 412 (1978).

184 Ohralik, 436 U.S. at 467-68.

185 Primus, 436 U.S. at 439.

186 Ohralik, 436 U.S. at 450. 
offered services free of charge (though still received salary from the ACLU). ${ }^{187}$ And, so the argument might go, it follows that a corporation, in seeking a profit when offering legal services, should be treated more like an ambulance chaser than an ACLU lawyer. I disagree. A Wal-Mart-law-type delivery mechanism, for all practical purposes, need not be anything like the proverbial ambulance chaser. Rather than rushing in to prey on the vulnerable accident victim, we instead would have access to a de-mystified legal services provider, where customers could learn about services in a neutral atmosphere as they conduct everyday shopping.

Of course, this is not to suggest that the states may not regulate aspects of nonlawyer corporate law practice ownership and investment. Indeed, they can and they should. ${ }^{188}$ The Court reinforced this distinction between an outright ban and appropriate regulation in Citizens United, holding that in the political campaign context, "[t]he Government may regulate corporate political speech through disclaimer and disclosure requirements, but it may not suppress that speech altogether."189 Law practice ownership/investment by corporations should be treated the same way.

Moreover, the Supreme Court recently decided another commercial speech case that further supports an expanded reading of Button and its progeny. In Sorrell v. IMS Health, Inc., the Court held that a Vermont statute restricting the sale and use of pharmacy records to so-called data miners violated the First Amendment. ${ }^{190}$ Writing the 6-3 majority opinion, Justice Kennedy reaffirmed the view of the Bates Court that the "consumer's concern for the free flow of commercial speech often may be far keener than his concern for urgent political dialogue." $191 \mathrm{He}$ further observed that "the creation and dissemination of information are speech within the meaning of the First Amendment."192

The Sorrell Court's recognition that "creation and dissemination of information" constitutes protected speech under the First Amendment ${ }^{193}$ is critical to understanding the constitutional significance of corporate delivery of legal services. The corporation is uniquely situated to engage in wide-scale creation and dissemination of legal representation in a way that currently does not occur largely due to cost restraints associated with economies of scale. It simply is not economically feasible for a traditional law firm to market and deliver en masse representation to the general public for routine wills, child

187 Primus, 436 U.S. at 422.

${ }^{188}$ For example, in one of the more recent lawyer advertising cases to reach the Court, the majority upheld a thirty-day ban on direct-mail solicitation targeted to accident victims, reasoning that while states cannot prohibit advertising speech outright, they may regulate it.

See Fla. Bar v. Went For It, Inc., 515 U.S. 618, 620 (1995).

${ }^{189}$ Citizens United v. FEC, 130 S. Ct. 876, 886 (2010).

190131 S. Ct. 2653, 2672 (2011).

${ }^{191} I d$. at 2664 (quoting Bates v. State Bar, 433 U.S. 350, 364 (1977)) (internal quotation marks omitted).

192 Id. at 2667 (emphasis added).

${ }^{193}$ Id. 
custody, divorce, mortgage foreclosure, standard contracts, small business needs, immigration, bankruptcy, housing disputes, and other basic matters.

One significant difference between the lawyer-advertising cases and the ban on corporate delivery of legal services is that the former regulated speech, not speakers, whereas in the latter, potential speakers are excluded. As a result, not only are corporations unable to engage with lawyers to deliver legal services, but an entire realm of potential speech about access to law is, effectively, shut down. In the following discussion, I explain how Citizens United lends further force to my argument that corporations hold a First Amendment right to deliver legal services, thereby increasing speech about the law and enhancing access to it.

\section{E. Corporate Speech: Citizens United v. FEC}

Citizens United-while involving very different facts on its face than those presented by corporate ownership of law practices - accomplished at least two tasks related to our understanding of the free speech interests bound up in access to the law and the delivery of legal services: (1) the majority reaffirmed the strength of First Amendment protections afforded to corporations, ${ }^{194}$ and (2) the holding of the case broadens.prior decisions related to the need for speech to further economic competition. The Court applied strict scrutiny on political speech grounds to strike down a federal law prohibiting corporations and unions from spending general funds as independent expenditures for "electioneering communication" or "speech expressly advocating the election or defeat of a candidate."195 Justice Kennedy, writing the 5-4 opinion, explained that the federal law's purpose was "to prevent corporations ... from presenting both facts and opinions to the public."196 Such a purpose runs counter to the principle, he explained, "that the Government may not suppress political speech on the basis of the speaker's corporate identity. No sufficient governmental interest justifies limits on the political speech of nonprofit or for-profit corporations."197 Kennedy further observed that "[c]orporations and other associations, like individuals, contribute to the discussion, debate, and the dissemination of information and ideas that the First Amendment seeks to

194 See Citizens United, 130 S. Ct. at 900 ("The Court has thus rejected the argument that political speech of corporations or other associations should be treated differently under the First Amendment simply because such associations are not natural persons." (internal quotation marks omitted)). But see Jeffrey D. Clements, Beyond Citizens United v. FEC: ReExamining Corporate Rights, ADVANCE, Fall 2010, at 37, 42-43 ("Repeatedly, the Court has held that corporations are not citizens under [the Privileges and Immunities Clause of Article IV], or ... the Fourteenth Amendment.").

195 Citizens United, 130 S. Ct. at 886, 898-99 (internal quotation marks omitted).

196 Id. at 907.

${ }^{197} \mathrm{Id}$. at 913. 
foster."198 Under this reasoning, Citizens United can be understood to extend to all corporations the right to engage with lawyers in the delivery of legal services as protected by Button (for constitutional rights and civil rights) and the union cases (for other matters).

Over the years the Court has upheld a number of restrictions involving speech related to lawyers, ${ }^{199}$ and in most of these cases the restriction was justified, at least in part, by an interest in allowing the state bar (or Congress, as was the case during the $2009 \mathrm{Term}^{200}$ ) to perform its functions. ${ }^{201}$ The Citizens United majority identified other contexts where "a narrow class of speech restrictions . . . that operate to the disadvantage of certain persons . . . based on an interest in allowing governmental entities to perform their functions" was upheld. ${ }^{202}$ Nevertheless, the "corporate independent expenditures at issue" in Citizens United were found to "not interfere with governmental functions, so these cases are inapposite." 203 The same can be said for corporate financing of law practices. As the majority concluded, "We find no basis for the proposition that, in the context of political speech, the Government may impose restrictions on certain disfavored speakers. Both history and logic lead us to this conclusion." 204 Likewise, it follows that in the context of Button's protected

${ }^{198}$ Id. at 900 (quoting Pac. Gas \& Elec. Co. v. Pub. Util. Comm'n, 475 U.S. 1, 8 (1986)) (internal quotation marks omitted).

${ }^{199}$ For a comprehensive list of cases addressing the First Amendment and the regulation of attorney speech, see Knake, supra note 20, at 660-63.

200 See Renee Newman Knake, The Supreme Court's Increased Attention to the Law of Lawyering: Mere Coincidence or Something More?, 59 AM. U. L. REV. 1499, 1499-1500, 1508-13 (2010) (discussing the Court's validation of federal statutes constraining legal advice in Milavetz, Gallop \& Milavetz, P.A. v. United States, 130 S. Ct. 1324 (2010), and Holder v. Humanitarian Law Project, 130 S. Ct. 2705 (2010), two cases decided during the 2009 Term).

${ }^{201}$ See Zauderer v. Office of Disciplinary Counsel, 471 U.S 626, 642 (1985) (holding that disciplinary rules could mandate disclosure regarding payment of costs in advertisement, but that the First Amendment protected attorney so long as the advertisement was truthful and nondeceptive); see also Milavetz, $130 \mathrm{~S}$. Ct. at 1329, 1331 (applying Zauderer to uphold mandated disclosure in advertising by lawyers for bankruptcy-related services); Fla. Bar v. Went For It, Inc., 515 U. S. 618, 620 (1995) (holding that a thirty-day prohibition on direct-mail solicitation by lawyers of personal injury or wrongful death clients withstood First Amendment scrutiny); Ohralik v. Ohio State Bar Ass'n, 436 U.S. 447, 449 (1978) (upholding ban on in-person solicitation of personal injury victims). See generally W. Bradley Wendel, Free Speech for Lawyers, 28 HASTINGS CONST. L.Q. 305 (2001) (exploring lawyer-related free speech issues in a variety of contexts).

202 Citizens United, $130 \mathrm{~S} . \mathrm{Ct}$. at 899 (listing governmental entities such as public schools, the corrections system, the military, and federal civil service).

${ }^{203} \mathrm{Id}$. ("These precedents stand only for the proposition that there are certain governmental functions that cannot operate without some restrictions on particular kinds of speech. By contrast, it is inherent in the nature of the political process that voters must be free to obtain information from diverse sources in order to determine how to cast their votes.").

${ }^{204}$ Id. 
delivery of legal services, the government may not impose restrictions on disfavored speakers, in this case the corporation.

Justice Scalia, concurring in the judgment, further explained that freedom of speech includes "the freedom to speak in association with other individuals, including association in the corporate form." 205 In this way, Citizens United expands to for-profit corporations Button's protections for the association of nonprofit corporations and lawyers to deliver legal advice and advocacy:

[T]hat state law grants corporations special advantages-such as limited liability, perpetual life, and favorable treatment of the accumulation and distribution of assets ... does not suffice ... to allow laws prohibiting speech. It is rudimentary that the State cannot exact as the price of those special advantages the forfeiture of First Amendment rights. ${ }^{206}$

And Justice Kennedy, in authoring the majority opinion, emphasized that where a question exists about the protection warranted, the First Amendment demands we "give the benefit of any doubt to protecting rather than stifling speech."207

Notwithstanding the Court's holding, Professor Jeffrey Clements argues that "[n]othing in the First Amendment requires that states, Congress, and the Court ignore the capacity of the 'speaker' when that very capacity exists as a result of government policy."208 The First Amendment value, however, is not concerned with who is speaking but rather with the speech itself and the delivery of it. What can be more valuable than speech about the entitlements, obligations, and prohibitions under the law or the method used to deliver that speech broadly?

As in the earlier discussions of Button, Velazquez, and the commercial speech cases, the rights of the listener also are relevant to the Court's decision in Citizens United and to the analysis here. Justice Kennedy explains that "[w] hen Government seeks to use its full power . . . to command where a person may get his or her information or what distrusted source he or she may not hear, it uses censorship to control thought. This is unlawful. The First Amendment confirms the freedom to think for ourselves." 209 The protected expression for the listener (or, in the case of corporate ownership, the prospective client) is as important as the protected expression for the speaker, or the corporation. ${ }^{210}$ As

${ }^{205}$ Id. at 925 (Scalia, J., concurring, joined by Alito, J., and joined in part by Thomas, J.).

${ }^{206} \mathrm{Id}$. at 905 (majority opinion) (citations omitted) (internal quotation marks omitted).

${ }^{207}$ Id. at 891 (quoting FEC v. Wis. Right to Life, Inc., 551 U.S. 449, 469 (2007) (Roberts, C.J.) (citing N.Y. Times Co. v. Sullivan, 376 U.S. 254, 269-70 (1964))) (alteration omitted) (citation omitted) (internal quotation marks omitted).

208 Clements, supra note 194, at 44.

209 Citizens United, 130 S. Ct. at 908.

${ }^{210}$ See, e.g., Fla. Bar v. Went For It, Inc., 515 U.S. 618, 635 (1995) (Kennedy, J., dissenting, joined by Stevens, Souter, and Ginsburg, J.J.) ("The Court today undercuts this guarantee in an important class of cases and unsettles leading First Amendment precedents, at the expense of those victims most in need of legal assistance."). 
Button and the union cases teach us, this is especially true when the listener/client is a prospective client receiving advice about the enforcement of constitutional or other rights. This is equally true, under the reasoning of Velazquez, when the listener is the judiciary.

A word about Citizens United's impact on commercial speech is also warranted here. Professor Randall Bezanson argues that in applying strict scrutiny, the Citizens United majority "reject[ed] value or usefulness as relevant at all and... infuse[d] the corporation with the liberty and freedom accorded the individual under the First Amendment." 211 Consequently, he observes, "it will be impossible in principle to treat commercial speech by corporations as anything less than fully protected speech."212 Similarly, Professor Tamara Piety contends that the Citizens United characterization of corporations as "citizens,' as if they were real persons[,] . . bolsters arguments for treating commercial speech like fully protected speech because it trains the analysis on the speaker instead of the listener."213 Whether Citizens United sounded the death knell for commercial speech doctrine as suggested by Professors Bezanson and Piety is beyond the scope of this Article. In the limited context of legal services delivery, however, which involves bans on external investment that, in essence, function as content regulation that suppresses ideas, it is difficult to see how the Court can maintain this artificial distinction between political versus commercial speech.

As the foregoing discussion reveals, commercial speech about the delivery of legal services is inherently political speech, speech that goes to the heart of meaningful access to the law, speech deserving of the strongest protection that the Constitution offers. Of course, we need not go so far as to collapse the two tests entirely, even if some commentators foresee this as a possibility. ${ }^{214} \mathrm{Model}$ Rule 5.4's blanket ban on corporate ownership of law practices runs afoul of the First Amendment whether we apply strict scrutiny or commercial speech scrutiny. Under strict scrutiny, even assuming the government has a compelling interest in banning such ownership structures based upon concerns of lawyer independence, professionalism, and client protection, the total prohibition is not

${ }^{211}$ Bezanson, supra note 56, at 659. For a pre-Citizens United argument against the commercial-political speech distinction in the context of corporate governance speech, see Henry N. Butler \& Larry E. Ribstein, Corporate Governance Speech and the First Amendment, 43 U. KAN. L. REV. 163, 205 (1994) ("Even if the dubious distinction between commercial and political speech continues to be accepted, regulation of corporate governance speech should be subject to a high level of scrutiny under the First Amendment.").

212 Bezanson, supra note 56 , at 659 .

213 Piety, supra note 58, at 16 . Professor Piety goes on to address the inevitable consequences of treating commercial speech as fully protected, noting in particular that this "would likely strangle in their infancy recent and proposed regulatory reforms such as the new tobacco regulation, the financial reform act[,] . . a and the Interagency Agency Working Group on Foods Marketed to Children ... to name just a few." Id. at 16-17 (footnotes omitted).

${ }^{214}$ See discussion supra notes $174-78$ and accompanying text. 
narrowly tailored to achieve these objectives, nor is it the least restrictive means for doing so. Likewise, under Central Hudson's test for commercial speech, again even assuming the government's interest is substantial, the complete ban is more restrictive than necessary.

\section{Wal-MartLaw, Googlelaw, COMING SOON . . .}

The primary focus of my argument rests on the First Amendment jurisprudential thread sparked by $N A A C P$ v. Button, but it is notable that the Court's expansion of First Amendment rights for corporations parallels the economics of law practice and the regulatory changes taking place in other countries. My reading of the First Amendment jurisprudence corresponds with the normative concerns of market competition and access to the law. Now is the time for bar authorities, academics, members of the legal profession, and others to begin exploring, and, importantly, embracing the reality of corporate ownership and investment for law practices. A number of scholars and experts already are engaging in this endeavor, and we soon will have the benefit of learning from recent reforms in Australia and the United Kingdom that allow for nonlawyer ownership of law practices.

Several noted law professors, business scholars, and economists also have weighed in on the side of nonlawyer corporate ownership. Professors Edward Adams and John Matheson published in 1998 a leading article that advances this position. ${ }^{215}$ Their work offered a detailed history of the ban on corporate ownership and refuted arguments levied against corporate ownership of law practices over the years, such as "fear of corporate giants, interference with professional independence and judgment, breaching of client confidences, unauthorized practice of law, and the danger of the legal profession becoming too businesslike." 216 Instead, they advocated for the lifting of state restrictions on nonlawyer investment in law practices and indicate that the benefits of this proposal "include capital for expansion, capital for investment in new technologies and new lawyers, financing for contingency fee cases, and a myriad of other rewards."217

Likewise, Professor Larry Ribstein repeatedly advanced arguments favorable to lifting the ownership and investment restrictions. For example, in his article, The Death of Big Law, he described possible forms including: (1) outright incorporation of a law firm with a dual-level of shares for giving lawyers control; (2) the sale of legal services by in-house counsel; (3) multidisciplinary firms; and (4) retail operations like Wal-Mart. ${ }^{218}$ In an earlier essay, Want to Own a Law Firm?, Ribstein asserted that the public trading of

215 See generally Edward S. Adams \& John H. Matheson, Law Firms on the Big Board?: A Proposal for Nonlawyer Investment in Law Firms, 86 CALIF. L. REV. 1 (1998).

216 Id. at 40; see also id. at 14-24.

217 Id. at 40.

218 See Larry E. Ribstein, The Death of Big Law, 2010 WIS. L. REv. 749, 792, 797-800. 
law firms "would make it harder for lawyers and law firms to deny that they really are businesses," resulting in a benefit, in that "[i]nstead of driving out the last vestige of professionalism, going public will clarify professionalism's role in the business of law practice." 219 Professor Laurel Terry also has pressed authorities to consider the economic rationale for legal services regulation. ${ }^{220}$ While Ribstein and scholars like Mitt Regan, Charles Wolfram, and others would advocate relaxing, if not removing, the restrictions, ${ }^{221}$ some remain resistant. 222

${ }^{219}$ Larry E. Ribstein, Want to Own a Law Firm?, AMERICAN (May 30, 2007), http://www.american.com/archive/2007/may-0507/want-to-own-a-law-firm.

${ }^{220}$ See, e.g., Laurel S. Terry, Understanding the Economic Rationale for Legal Services Regulation: The Importance of Interdisciplinary Dialogue 11 (Mar. 2011) (unpublished manuscript), available at http://ssm.com/abstract=1909644.

${ }^{221}$ See Mark I. Harrison \& Mary Gray Davidson, The Ethical Implications of Partnerships and Other Associations Involving American and Foreign Lawyers, 22 PENN ST. INT'L L. REV. 639, 639 (2004) ("address[ing] the impact of globalization on legal services and the ethical issues raised by the phenomenon in which U.S. and non-U.S. lawyers form partnerships and other associations"); Bruce MacEwen, Milton C. Regan, Jr. \& Larry Ribstein, Conversations: Law Firms, Ethics, and Equity Capital, 21 Geo. J. LeGAL ETHICS 61, 63-64, 67 (2008) (discussing the impact of the United Kingdom's Legal Services Act 2007 on American law firms and reflecting on whether "a derivative instrument structured to reflect the implicit value of the firm" violates Model Rule 5.4); Paul D. Paton, Multidisciplinary Practice Redux: Globalization, Core Values, and Reviving the MDP Debate in America, 78 FORDHAM L. REV. 2193, 2196, 2198 (2010) (providing "a historical review of the MDP debate in the United States and Canada and a summary of changes in England and Australia that set the stage for the Ethics 20/20 [Commission]"); Milton C. Regan, Jr., Lawyers, Symbols, and Money: Outside Investment in Law Firms, 27 PEnN ST. INT'L L. REv. 407, 407-08 (2008) (describing the public offering of Australian firm Slater \& Gordon and the United Kingdom's Legal Services Act of 2007, and reviewing the consequences for American lawyers of moving from a self-regulated to a regulated industry model); Laurel S. Terry, A Primer on MDPs: Should the "No" Rule Become a New Rule?, 72 TeMP. L. Rev. 869, 873 (1999); Charles W. Wolfram, The ABA and MDPs: Context, History, and Process, 84 MINN. L. REV. 1625, 1652 (2000) ("Such kinds of bar turf protection suggest impressive political power and might make a kind of greedy economic sense for some lawyers in private practice, but little else can be said in its favor. Many 'unauthorized practice' restrictions that have the direct and palpable effect of constricting consumers' choice of service providers feed popular images of the bar as a guild whose -primary activity is professional self-aggrandizement. For the public, the loss has been acute. Surely, an increase in MDP opportunities would provide more widespread and innovative legal services, as well as more client choice in shopping for legal services."); id. at 1654 ("During much of the past century, the bar engaged in another debate-whether law was a business or a profession. The answer, of course, is that it is both. The business of law and the business of business are not oil and water as they are sometimes claimed to be by MDP opponents. Properly regulated to deal with real (rather than imagined) problems, law and business can function well together. It remains to be seen whether the ABA has a similar faith in both lawyers and allied professions, and in the wisdom and common sense of law's own clientele."); Heather A. Miller, Note, Don't Just Check "Yes" or "No": The Need for Broader Consideration of Outside Investment in the Law, 2010 U. ILL. L. REV. 311, 311 (addressing "the controversial issue of outside investment in law firms" and "analyz[ing] 
In addition to the current body of scholarship and commentary on nonlawyer ownership of law practices, lessons stand to be gained from the experiments of nonlawyer ownership and investment in Australia and the United Kingdom, and those under consideration in other countries around the world. For example, New South Wales passed legislation in July 2001 authorizing incorporated legal practices including multidisciplinary practices. ${ }^{223}$ In May 2007, Slater \& Gordon, a large plaintiffs' law firm, "became the first law firm in the world to list its entire practice on the Australian Stock Exchange."224 By April 2009, nearly 900 Australian firms in New South Wales had become incorporated legal practices, a number of which incorporated as multidisciplinary firms, and two of which currently list on the Australian Stock Exchange. ${ }^{225}$

five investment models"); Bernard Sharfman, Note, Modifying Model Rule 5.4 to Allow for Minority Ownership of Law Firms by Nonlawyers, 13 GEO. J. LEGAL ETHICS 477, 480 (2000) (recommending "the modification of Model Rules 5.4(b) and (d) to allow for nonlawyer minority ownership of law firms for investment or other purposes"); Andrew von Nordenflycht, The Demise of the Professional Partnership? The Emergence and Diffusion of Publicly-Traded Professional Service Firms 42 (Nov. 2008) (unpublished manuscript), available at http://www.law.georgetown.edu/LegalProfession/documents/vonNordenflycht Paper.pdf (challenging "the common assumption that the large professional partnership has thrived because it suits the economic environment of the professional services, specifically by providing advantages in the attraction, motivation and development of human capitalists" and suggesting "that the absence of outside ownership in the professional services stems primarily from two distinctive characteristics: (1) professional norms about appropriate models of ownership and conflicts of interest; and (2) the typically small size of the firms").

222 See James R. DeBuse, Note, Opening at \$25 1/2 Is Big Firm U.S.A.: Why America May Eventually Have a Publicly Traded Law Firm, and Why Law Firms Can Succeed Without Going Public, 34 J. CORP. L. 317, 319 (2008) (recommending against public ownership of law firms and proposing as an alternative that "firms should mimic going public by going through most of the steps of preparing for public ownership," and concluding that by doing so, "firms will force themselves to focus on long-term stability and organizational capital"); Chandler N. Hodge, Note, Law Firms in the U.S.: To Go Public or Not to Go Public?, 34 U. DAYTON L. REV. 79, 80 (2008) (concluding that "although the international legal community is embracing the idea of publicly traded law firms, the U.S. and its legal community is better served by ... keeping ownership and management of law firms in the hands of lawyers and only lawyers"). See generally Fox, supra note 60.

${ }^{223}$ See Mark, supra note 49, at 47.

${ }^{224}$ Andrew Grech \& Kirsten Morrison, Slater \& Gordon: The Listing Experience, 22 GeO. J. Legal ETHICS 535, 535 (2009); see also Mark, supra note 49, at 53 ("Slater \& Gordon is an Australian law firm specializing in personal injury, commercial, family and asbestos-related class action law[,] ... [ [and] is one of Australia's most successful and wellknown plaintiff law firms....”). Anticipating questions about the preservation of the lawyer's professional independence in this arrangement, the Slater \& Gordon prospectus provides "that where an inconsistency or conflict arises between the duties of the company (and the duties of the lawyers employed by the company), the company's duty to the court will prevail over all the duties and the company's duty to its clients will prevail over the duty to shareholders." Id. at 55 (citation omitted).

${ }^{225}$ Mark, supra note 49, at 55. 
The United Kingdom approved a comprehensive overhaul for the regulation of legal services in October 2007, known as the Legal Services Act. ${ }^{226}$ Among its many provisions, the Act provides for corporate involvement in the investment and management of law firms. For example, the United Kingdom's "leading supermarket chain," Tesco, has experimented over the years in offering legal services by contracting with outside lawyers, but now will be able to do so directly.227 The services include will writing, do-it-yourself divorce kits, rental agreements, and forms for setting up a small company. ${ }^{228}$ By virtue of its use of the concept, Tesco has been described by some "as a pioneer in this area and reports suggest that other high street businesses will follow their lead, perhaps expanding on what Tesco [is] offering, especially in light of the ownership reform rules." 229

Other large retailers in Great Britain have revealed plans to do exactly that, whether through a venture similar to that contemplated by Tesco or through a partnership to utilize retail space like that envisioned by QualitySolicitors as it moves into WHSmith stores. ${ }^{230}$ Additional businesses that are developing innovative ways to deliver legal services as this Article goes to print include Legal365, LawVest, Parabis Law, Lawyers2You, and more. ${ }^{231}$ These alternative business structures are not without critics, and they have met strong resistance from barristers and solicitors who contend that the idea of retailpartnerships "provid[ing] legal services is a recipe for disaster." 232 They predict, reminiscent of the arguments against lawyer advertising in the United States, that:

Services by these brands will inevitably be provided by unqualified call centre staff, probably outside the UK, overseen by an inadequate number of in-house solicitors. The solicitor profession faces being all but wiped out by a

${ }^{226}$ For a history and discussion of the United Kingdom's Legal Services Act, see Whelan, supra note 28, at 467. See also Andrew Boon, Professionalism Under the Legal Services Act 2007, 17 INT'L J. LEGAL PROF. 195, 195 (2010), available at http://ssm.com/abstract=1911139.

${ }^{227}$ Jane O'Shea, Tesco Legal Services, ATT'y MARKETING Blog (Apr. 23, 2010), $\mathrm{http} / / / \mathrm{www}$.attorneymarketingnetwork.com/tesco-legal-services/ (Regulators see this as responding to a need "for an increase in cheaper and more accessible legal advice.").

228 Id.

229 Id.

${ }^{230}$ See discussion supra note 31; see also Frances Gibb, Co-Op Steals a March on Tesco in the Race for New Customers, TIMES, Aug. 27, 2009, at 51, available at $\mathrm{http} / / /$ business.timesonline.co.uk/tol/business/law/essay6811153.ece.

231 See Neil Rose, Focus: Alternative Business Structures-Law and New Order, LAWYER, Nov. 7, 2011, at 14, 14-15, available at http://www.thelawyer.com/focusalternative-business-structures-law-and-new-order/1010138.article.

${ }^{232}$ Helen Loveless, Solicitors' Challenge to Tesco as Government Unveils Plan for Supermarket Legal Advice, DAILY MAIL (May 2, 2009), http://www.dailymail.co.uk/money/ essay-1176678/Solicitors-challenge-Tesco-Government-unveils-plans-supermarket-legaladvice.html (internal quotation marks omitted). 
Government seemingly intent on robbing the public of access to good-quality, local legal advice. 233

Reframing this debate, Professor Christopher Whelan explains:

In the United Kingdom, the idea that the lawyer's professional function is an essential condition in society has been flatly rejected. The predominant political view which seems to have emerged is that legal services ought to be treated more like a business than a profession; they should be regulated by the market rather than by professional self-regulation. ${ }^{234}$

Time will tell the accuracy of the predictions on both sides. Regardless, U.S. regulators stand to learn much from the Australian and United Kingdom examples.

Professor John Flood, an expert on regulation of the legal profession in the United Kingdom, forecasts that the changes fueled by the Legal Services Act "are the most profound in [the legal profession's] history." 235 He notes that people are skeptical of lawyers, "but they won't mind buying legal services in a setting [like Wal-Mart that] they know on a daily basis at a price that is clearly stated."236 Professor Richard Susskind contends that the liberation of lawyers and nonlawyers alike through these regulatory changes will cultivate "new and improved ways of delivering conventional services and will create novel markets and opportunities where none had been recognized before."237 Likewise, Professor Tom Morgan observes that many law firms are already functioning like corporations in their management style, and argues that it follows that nonlawyers should be permitted to invest in the firm or share in the fees earned by the firm. ${ }^{238}$ In Morgan's view, "[a]n actual market in shares of a law firm would give lawyers an incentive to build value and reduce the moral hazard inherent in decisions about whether to take, or how to handle, a case."239 $\mathrm{He}$ further contends that "a desire to attract and retain outside investors may tend to impose financial and behavioral discipline on law firms whose members have not experienced serious pressure to exercise it."240 Altering Model Rule 5.4 to allow for nonlawyer ownership and investment, according to Morgan, "should benefit firms, the firms' clients, and the public."241

Permitting external ownership and investment need not occur at the expense of professionalism or lawyer independence-the arguments historically raised

233 Id. (internal quotation marks omitted).

234 Whelan, supra note 28 , at 491.

235 Lisa G. LeRman \& Philip G. SChrag, Ethical Problems in the Practice of LaW 815 ( 2 d ed. 2008) (citation omitted).

236 Id.

${ }^{237}$ SUSSKIND, supra note 2, at 253-54.

238 See ThOMAS D. MORGAN, THE VANISHING AMERICAN LAWYER 168-69 (2010).

239 Id. at 169.

240 Id. at 170 .

241 Id. 
by American bar regulators to resist reform of Model Rule 5.4.242 Indeed, at the time of this writing, the ABA Commission on Ethics 20/20, charged with revision of the Model Rules of Professional Conduct to address changes in the legal profession driven by technology and globalization, continues to express caution and resistance. ${ }^{243}$ The Commission declined to recommend allowing full nonlawyer ownership and investment, ${ }^{244}$ though it expressed a willingness to consider minority activity. ${ }^{245}$ Even if the ABA were to adopt a proposal allowing minority nonlawyer ownership, such an arrangement is unlikely to generate the revolutionary change necessary for delivering meaningful legal representation on a mass scale.

The Commission's position fails to account for (or fully appreciate) the realities of the "paradigm shift" that has occurred in the legal profession over the past twenty years, a shift first identified by Professor Russell Pearce and others. 246 Pearce suggests that "professionalism" for the legal profession "is socially constructed," meaning that "[i]ts authority rests not on its truth in any abstract sense, but in its acceptance by the relevant community." 247 Under the professionalism paradigm, "lawyers differ from businesspersons in that they possess esoteric knowledge inaccessible to lay persons," and "in contrast to businesspersons, who maximize financial self-interest, lawyers altruistically place the good of their clients and the good of society above their own selfinterest." 248 External regulation of the profession, so the argument goes, is then "both impractical and unnecessary" due to this "combination of inaccessible knowledge and altruism." 249 Lawyer independence is purportedly preserved by this artificial notion of adhering to professionalism rather than the profit-motive.

The professionalism/independence paradigm ignores the economic realities of law practice. The fact is that law practice is a business-one increasingly pressured in the twenty-first century by competition and technological innovation. In order to "implement" professionalism (or perhaps avoid external regulation), the legal profession, according to Pearce, historically "proscribed business conduct as taboo," vilifying the "Profit Maximizer [who] openly

${ }^{242}$ See Letter from ABA Comm'n, supra note 43, at 6.

243 See id. at 2.

${ }^{244}$ See id. at 6.

245 See Ethics 20/20 Commission Approves Release of Draft to Allow Nonlawyer Owners in Firms, 27 Law. Manual on Prof. Conduct (ABA/BNA) 505, 527 (Aug. 17, 2011), available at http://www.bna.com/ethics-2020-commission-n12884903114/.

${ }^{246}$ See Russell G. Pearce, The Professionalism Paradigm Shift: Why Discarding Professional Ideology Will Improve the Conduct and Reputation of the Bar, 70 N.Y.U. L. REV. 1229, 1229 (1995); see also Knake, supra note 200, at 1560-64 (discussing recent Supreme Court cases and commentary by other scholars "recognizing the consequences of increased federal regulation and the classification of lawyers as gatekeepers or service providers"); Laurel S. Terry, The Future Regulation of the Legal Profession: The Impact of Treating Lawyers as "Service Providers," 2008 J. Prof. LAW. 189, 189.

247 Pearce, supra note 246 , at 1231.

248 Id.

${ }^{249} \mathrm{Id}$. 
markets legal services and competes with other lawyers" tempting "lawyers to cut ethical corners in search of a buck." 250 This sort of thinking undergirds the rationale for Model Rule 5.4's ban on outside ownership and investment of law firms. As an alternative, Pearce proposes a "Middle Range" approach to address professionalism's concerns with the business pressures of law practice. ${ }^{251} \mathrm{He}$ conceptualizes a model where the lawyer's independence stems not from professionalism motives, but from a moral source. 252 His proposal "combines the advantages of a market system with a communitarian moral vision and retains a place, though a limited one, for the current institutions of the bar." 253

Pearce advanced this approach to justify permitting nonlawyers to practice law in certain circumstances, but his approach offers guidance for responding to the concerns raised here about Model Rule 5.4 as well. Permitting nonlawyers to provide legal services, according to Pearce, could lead to a number of advantages similar to what Susskind, Morgan, Ribstein, and others have predicted about nonlawyer ownership and investment: (1) improved quality of legal services, (2) lower costs for consumers, especially less sophisticated consumers of legal services, (3) enhanced competition resulting in greater incentives for lawyers to practice law competently and ethically, (4) increased access to legal services for moderate and low-income individuals, and (5) greater respect for the legal profession. ${ }^{254}$

This, of course, begs the question of what might be lost by removing the external ownership ban from Model Rule 5.4. I acknowledge that opening access to the law in this way may very well run the risk of compromising the administration of justice and the rule of law if not encompassed by sufficient protections to preserve lawyer independence. I also acknowledge that this restructuring of Model Rule 5.4 likely will result in an increasingly institutionalized delivery of legal services. This may mean that legal representation could become less personal, that individual lawyers may do less pro bono work, that some solo practitioners will need to join with others in order to remain viable, and that we may be entering a world where insurance companies play a stronger role in the legal services market. Yet, these risks are equally present (if not more threatening) should Model Rule 5.4 remain unchanged. The economic realities of twenty-first century law practice pose a host of challenges to lawyer independence, ranging from the pressure of massive educational debt held by many recent law graduates to the mounting inefficiency of the billable hour. Indeed, external investment may be the very thing that preserves lawyer independence-especially given the burdens of law school debt, billing inefficiencies, and leveraging of overhead costs-thereby

${ }^{250} \mathrm{Id}$. at $1242-43$ (citations omitted).

251 See id. at 1267-75 (discussing proposal for a "Middle Range" approach as an alternative to "the status quo and market alternatives").

${ }^{252}$ Id. at 1270.

253 Pearce, supra note 246, at 1269.

${ }^{254}$ See id. at $1272-74$. 
allowing for meaningful pro bono representation because the lawyer no longer needs to worry about maintaining a case-by-case cash flow.

The work of Susskind, Morgan, Pearce, and others offers practical support for the jurisprudential First Amendment thread identified by this Article, and we are likely to see more work like theirs arguing for the systemic and individual gains that might be realized through decreased and/or reformed regulation. ${ }^{255}$ Their observations about the future of the legal profession demonstrate that corporate ownership and investment of law practices can democratize legal services delivery, provided that mechanisms remain in place to ensure lawyer independence and client protection. Susskind argues that much work on access to justice is mere lip service, and that we must press for a "richer analysis."256 To do so, Susskind suggests that:

Improving access to justice ... will require much improved facilities in place to support clients; to recognize that they need or would benefit from guidance on dispute resolution, dispute avoidance, and legal health promotion; to help them identify and select the most appropriate source of guidance; and to ensure that a wide range of sources are indeed available. ${ }^{257}$

This "more ambitious" version of access to justice, Susskind predicts:

should also help us to liberate what I call 'the latent legal market.' I am alluding here to the innumerable situations, in the domestic and working lives of all non-lawyers, in which they need and would benefit from legal guidance (or earlier, more timely, or empowering insight) but obtaining that legal input today seems to be too costly, excessively time consuming, too cumbersome and convoluted, or just plain scary. I believe this market will be liberated by the availability of straightforward, no-nonsense, online legal guidance systems and by other methods of sourcing legal service. They will not always replace conventional legal service, but they will provide affordable, easy access to legal guidance where this may have been unaffordable or impractical in the past. 258

Traditional law practice lacks the ability, resources, and motivation to devise Susskind's "straightforward, no-nonsense, online legal guidance systems." 259 But the corporation does not. Corporations have significant financial ability and resources. Corporations have strong incentives to offer

${ }^{255}$ For example, as this Article neared publication, Clifford Winston, Robert W. Crandall, and Vikram Maheshri published their book, FIRST THING WE DO, LET'S DEREGULATE ALL THE LAWYERS (2011), arguing on empirical grounds that lawyers and law consumers would benefit from deregulation of the legal profession, $i d$. at 8 . In a forthcoming work, (De)Regulating Lawyers, I plan to address their argument in greater detail.

256 SUSSKIND, supra note 2, at 231.

257 Id. at 234 .

$258 \mathrm{Id}$.

${ }^{259} \mathrm{Id}$. 
simple, standard, routine legal services in bulk to currently unserved individuals where profits may be realized through economies of scale and only after a hefty initial investment. Corporations have broad reach to widely disseminate information while simultaneously preserving brand reputation and trustworthiness. And, as this Article has demonstrated, corporations hold important First Amendment interests related to the delivery of legal services. Most critically, the individuals in need of a lawyer in the United States today hold significant First Amendment interests in the delivery of legal services funded by corporations.

\section{CONCLUSION}

This Article is the first to identify a jurisprudential thread of cases supporting the corporation's First Amendment right to deliver legal services through an arrangement involving ownership of or investment in a law practice, notwithstanding bar regulators' historic distaste for such relationships. Proponents of corporate law practice ownership and investment maintain that this will bring affordable representation to the general population and address the well-documented, unmet need for lawyers. Opponents counter that corporate involvement will exacerbate the already poor reputation of lawyers, undermine lawyer independence, and subject lawyers to insurmountable conflicts of interests driven by a profit motive instead of service to the client. Neither side, however, seems to fully appreciate the First Amendment interests at stake in the delivery of legal services.

The blanket suppression of law practice ownership and investment by corporations under state professional conduct rules is unlikely to withstand a First Amendment challenge given the legacy of Button $v . N A A C P$, especially in a post-Citizens United world. This is not to say, however, that a corporation's delivery of legal services should be left completely unregulated. Now is the time to permit nonlawyer ownership and investment in law practice under an appropriate regulatory scheme that will facilitate competition, fuel innovation, and increase access to quality legal services. ${ }^{260}$

Independent of the merits of Model Rule 5.4 in the selection of business form, my analysis here is, in part, predictive of what the Supreme Court might do were it presented with this matter, and I offer this prediction in a cautionary spirit-one that regulators should consider resolving before the issue reaches the Court. While the line of Supreme Court decisions on lawyer speech discussed in this Article indicates that the First Amendment encompasses protection of legal services delivered by corporations, such an opinion from the Court likely would only perpetuate an already overly complicated and

${ }^{260}$ The bar would do well to heed the words of caution expressed by Chief Justice Burger in Bates v. State Bar: "Unfortunately, the legal profession in the past has approached solutions for the protection of the public with too much caution, and, as a result, too little progress has been made." 433 U.S. 350, 388 (1977) (Burger, C.J., concurring in part and dissenting in part). 
somewhat contrived jurisprudence. Moreover, I acknowledge that there are other ways to accomplish the goal of expanding the delivery of legal services without going through the First Amendment. Nevertheless, corporate ownership of law practices has the potential to democratize the delivery of legal services, particularly among those who currently go without representation. Whether this is achieved via the First Amendment or not remains an open question, but it is an important question to be considering given the evolution of the Court's jurisprudence on lawyer speech. 